\title{
Three New Shallow Species of Taeniogyrus and Rowedota (Echinodermata: Holothuroidea: Apodida: Chiridotidae: Taeniogyrinae) from Southern Japan
}

\author{
Yusuke Yamana ${ }^{1,4}$, Hayato Tanaka ${ }^{2}$, and Shu Nakachi ${ }^{3}$ \\ ${ }^{1}$ Wakayama Prefectural Museum of Natural History, Funo 370-1, Kainan, Wakayama 642-0001, Japan \\ E-mail: yamanamako@gmail.com \\ ${ }^{2}$ Research Center for Marine Education, Graduate School of Science, The University of Tokyo, \\ Hongo 7-3-1, Bunkyo-ku, Tokyo 113-0033, Japan \\ ${ }^{3}$ Kuroshio Biological Research Foundation, 560 Nishidomari, Otsuki, Kochi 788-0333, Japan \\ ${ }^{4}$ Corresponding author
}

(Received 16 March 2016; Accepted 5 April 2017)

http://zoobank.org/83A1A483-8D0E-4B0B-8C2B-0AF8B6D32A96

\begin{abstract}
Three new sea cucumbers collected in the intertidal and subtidal zone of southern Japan, Taeniogyrus mijim sp. nov., Rowedota chippiru sp. nov., and R. motoshimaensis sp. nov., are described. All three species display a small body size (approximately $10-20 \mathrm{~mm}$ ), light body colour (primarily a transparent solid colour), and a small number of digits in their tentacles (one pair or two). They are easily distinguished from each other and from other congeners by the number of digits and by ossicle size and shape. Among these species, the state of the tooth series on the inner margin of the wheel ossicles is an important defining feature, i.e., a continuous row in Taeniogyrus but interrupted by concavities in Rowedota. Also, each tooth is sharp in T. mijim, trapezoidal in R. chippiru, and semicircular in R. motoshimaensis. The number of teeth per radiant is 7-16 (means of 10-13 in different specimens) in T. mijim, 7-15 (means 9-12) in R. chippiru, and 8-21 (means 11-19) in R. motoshimaensis. Among these three new species, only R. chippiru has thick rod ossicles in the body wall.
\end{abstract}

Key Words: Holothuroidea, Apodida, Taeniogyrus, Rowedota, new species, Japan.

\section{Introduction}

Sea cucumbers of the order Apodida [or Synaptida; see Smirnov (2012) regarding their higher-level classification] were actively investigated in Japan in the past. Ohshima (1914) reported on "the Synaptidae of Japan" over 100 years ago and referred to 23 species, including most of those presently known in Japan. Especially in shallow waters, many new species of macroscopic apodids, such as Scoliorhapis dianthus Solis-Marin et al., 2014 (q.v.), have recently attracted the interest of researchers. In contrast, microscopically small species have been neglected. Prototrochus minutus (Östergren, 1905), a mere $4-6 \mathrm{~mm}$ long and $2-3 \mathrm{~mm}$ wide, was found at a depth of 60-65 $\mathrm{m}$ off the coast of Korea (Östergren 1905) and is the smallest known apodid species. All others described to date have been significantly larger, i.e., $>30 \mathrm{~mm}$ long, and no additional small species have been reported.

Recently, small apodid holothurians have been collected in sandy-gravel sediment in the intertidal zone of the coast of southern Japan, and these include some species that appear distinct from all others reported in Japan. In this report, three new species of the genera Taeniogyrus Semper, 1868 and Rowedota O'Loughlin and VandenSpiegel, 2010 are described.

Although there was considerable debate concerning the genus Taeniogyrus until recent years, it is presently well-defined morphologically (see below) and consists of 26 species (O'Loughlin and VandenSpiegel 2010; Paulay 2013; Moura et al. 2015; O'Loughlin et al. 2015). Originally, Semper (1868) separated the type species, T. australiana (Stimpson, 1855), from Chirodota Eschscholtz, 1829, defining Taeniogyrus based on the primary features of the wheel ossicles and sigmoid-hook ossicles in the skin of the body: wheel ossicles aggregated and forming papillae, and sigmoid-hook ossicles scattered uniformly. However, aggregations of wheel ossicles have been observed in only a few species besides the type species [e.g., Taeniogyrus cidaridis Ohshima, 1914 (q.v.); T. heterosigmus Heding, 1931 (q.v.)], and not observed in others. Therefore, some Taeniogyrus species that lack wheel papillae were thought to be better classified in the genus Trochodota Ludwig, 1891, which differs from Taeniogyrus primarily in the lack of aggregations of wheel ossicles (Ludwig 1898).

Both Taeniogyrus and Trochodota were considered valid for a long time, although it was difficult to draw a definite line of demarcation between them. Recently, O'Loughlin and VandenSpiegel (2010) revised them and concluded that Trochodota studeri (Theel, 1886), the type species of Trochodota, is a junior synonym of Holothuria (Fistularia) purpurea Lesson, 1830. Furthermore, they placed $H$. (F.) purpurea into Taeniogyrus, as T. purpureus (Lesson, 1830). This action led to six species of Trochodota being transferred into 
Taeniogyrus, and the remaining four being placed in the newly erected genus Rowedota O'Loughlin and VandenSpiegel, 2010. The difference between Taeniogyrus and Rowedota is the shape of the wheel ossicle: in Rowedota, the inner margin of the wheel rim becomes narrower in the corners, where the tooth series is interrupted by the resulting concavities (O'Loughlin and VandenSpiegel 2007, 2010). At the same time, aggregations of wheel ossicles were rejected from the generic diagnostic of Taeniogyrus. Instead, the number of tentacles (10 tentacles) was considered a good generic diagnostic character for Taeniogyrus (O'Loughlin and VandenSpiegel 2010).

\section{Materials and Methods}

Animals were collected from the lower intertidal zone of sandy-gravel shores at the following two sites in southern Japan: (MOT) Motoshima Islet, Mera, Tanabe, Wakayama $\left(33^{\circ} 43^{\prime} 56.0^{\prime \prime} \mathrm{N}, 135^{\circ} 20^{\prime} 58.0^{\prime \prime} \mathrm{E}\right), 21$ May, 17 June, 31 July, 29 August, and 29 September 2015, and 22 January 2016 (coll. Y. Yamana); (ARA) Araha Beach, Chatan, Okinawa $\left(26^{\circ} 18^{\prime} 08.9^{\prime \prime} \mathrm{N}, 127^{\circ} 45^{\prime} 27.7^{\prime \prime} \mathrm{E}\right.$ ), 14 September 2015 (coll. Y. Yamana); and from the subtidal zone at a depth of approximately $5 \mathrm{~m}$ in a sandy-gravel bottom at (NIS) Nishidomari, Otsuki, Kochi $\left(32^{\circ} 46^{\prime} 43.3^{\prime \prime} \mathrm{N}, 132^{\circ} 43^{\prime} 55.1^{\prime \prime} \mathrm{E}\right), 29$ October 2014 (coll. S. Nakachi).

Several scoops of sediment taken approximately $30 \mathrm{~cm}$ below the bottom surface were quickly washed with sea water in a bucket to suspend interstitial animals before the water was filtered through a $40-100 \mu \mathrm{m}$ mesh sieve. The specimens from these filtered samples were sorted alive under a binocular dissecting microscope (Nikon SMZ). Sorted specimens were fixed and preserved in $80 \%$ ethanol. Some of them were fixed after anaesthetization in a menthol solution $(0.37 \mathrm{~g}$ of menthol dissolved into $100 \mathrm{~mL}$ of $99 \%$ ethanol, this then being diluted to $3.0 \%$ with seawater) for 30 minutes.

All specimens in the type series were dissected and the tentacles, Polian vesicles, ciliated funnels, and calcareous rings were examined under a binocular dissecting microscope (Nikon SMZ); drawings of the tentacles and calcareous rings were made with a camera lucida. Ossicles from four regions of the body wall (dorsal anterior, dorsal posterior, ventral anterior, and ventral posterior) and the lateral tentacles were observed. Ossicles of the tentacles and dorsal anterior body wall were observed in all specimens; those in the other parts of the body wall were extracted from just three specimens of each species, thus avoiding major damage to most specimens. To extract ossicles, small pieces of tissue were isolated using sharpened ophthalmologic scissors under the dissecting microscope, and dissolved using sodium hypochlorite solution $(\mathrm{NaClO}, 5 \%)$. Ossicles extracted from all five body regions were mounted on glass slides in polyester resin (Showadenko RIGOLAC) and observed under a compound microscope (Nikon Optiphot). Several ossicles from the tentacles and the anterior dorsal body wall were rinsed with deionized water, dehydrated in
99\% ethanol, mounted on aluminium stubs using conductive tape (Nisshin NEM Tape), dried at room temperature, and observed using a scanning electron microscope (SEM) (Hitachi Miniscope TM-1000).

The ossicles were classified into 'wheels' (i.e., wheel-like ossicles with spokes and a series of teeth on the inner margin of the rim), 'sigmoid-hooks' (fishhook-like ossicles, with an open pointed end and closed blunt end, with the point of the hook turned outwards), 'rods' (rod-like ossicles, slightly curved, sometimes distally branching or spreading, sometimes centrally spinous), and 'thick rods' (thick rod-like ossicles, slightly curved, distally blunt with many minute processes). Measurements of 6-25 ossicles were taken for every tissue sample, to the nearest micrometre. To compare these measurements among individuals and among parts of the body, Kruskal-Wallis tests were performed. The dissected specimens, glass slides, and SEM material were deposited in the Invertebrate Collection (INV) of the Wakayama Prefectural Museum of Natural History (WMNH) in Kainan, Wakayama, Japan, and two specimens of NIS were deposited in the Echinodermata Collection (EC) of the Biological Institute of Kuroshio (BIK), Otsuki, Kochi, Japan.

DNA extraction from small pieces of ethanol-preserved tissue was performed using the DNeasy Blood and Tissue Kit (Qiagen, USA) following the manufacturer's protocol, except that the elution volume was reduced from $200 \mu \mathrm{l}$ to $100 \mu$ l because of the low expected amount of total DNA in the specimens. Partial sequences of the mitochondrial cytochrome $c$ oxidase subunit 1 (CO1) gene were PCR-amplified using the universal primer set (LCO1490/HCO2198; Folmer et al. 1994). This sequence region is the most commonly used for DNA barcoding to identify species (Hebert et al. 2003; Bucklin et al. 2011). The $25 \mu$ reaction mixture contained $0.125 \mu \mathrm{l}$ of TaKaRa Ex Taq HS (TAKARA BIO Inc., Japan), $2.5 \mu \mathrm{l}$ of $10 \times E x$ Taq buffer, $2 \mu \mathrm{l}$ of dNTP mix, $1 \mu \mathrm{l}$ of each primer ( 5 pmoles each), $3 \mu \mathrm{l}$ of template DNA, and $15.375 \mu \mathrm{l}$ of sterilized distilled water. The PCR protocol included an initial denaturation step at $95^{\circ} \mathrm{C}$ for $2 \mathrm{~min}$, followed by 40 cycles of denaturation at $95^{\circ} \mathrm{C}$ for $20 \mathrm{~s}$, annealing at $42^{\circ} \mathrm{C}$ for $30 \mathrm{~s}$, and extension at $72^{\circ} \mathrm{C}$ for $1 \mathrm{~min}$, and a final extension at $72^{\circ} \mathrm{C}$ for $10 \mathrm{~min}$. Quantity and length of the PCR products were checked by $1 \%$ agarose S (Nippon Gene, Japan) gel electrophoresis, stained with ethidium bromide. The products were purified for sequencing using the FastGene Gel/PCR Extraction Kit (NIPPON Genetics Co, Ltd, Japan) according to the manufacturer's protocol. Sequencing (of both the forward and reverse reads) was performed by Macrogen Japan Corp. (Tokyo) with the same primers that were used for PCR amplification. A homology search of CO1 sequences was performed by BLAST (Altschul et al. 1990, 1997) with the discontinuous Mega BLAST program from the National Center for Biotechnology Information (NCBI, http://blast.ncbi.nlm.nih.gov/Blast. cgi). 


\section{Taxonomy}

Order Apodida Brandt, 1835 (sensu Östergren, 1907)

Family Chiridotidae Östergren, 1898

Subfamily Taeniogyrinae Smirnov, 1998

Genus Taeniogyrus Semper, 1868

Taeniogyrus mijim sp. nov.

(Figs 1A, 2A, 3A, 4A, 5A, 6)

Material examined. Holotype: WMNH-2015-INV-1457 (MOT, 17 June 2015) (length $11.2 \mathrm{~mm}$, width $1.0 \mathrm{~mm}$ ). Paratypes: WMNH-2015-INV-1402 (MOT, 31 July 2015) (length $7.2 \mathrm{~mm}$, width $0.7 \mathrm{~mm}$ ); WMNH-2015-INV-1456 (MOT, 17 June 2015) (length $9.4 \mathrm{~mm}$, width $1.0 \mathrm{~mm}$ ); BIK-EC-T0200 (NIS, 29 October 2014) (length $6.0 \mathrm{~mm}$, width $0.4 \mathrm{~mm}$ ); BIK-EC-T0201 (NIS, 29 October 2014) (length $8.5 \mathrm{~mm}$, width $0.9 \mathrm{~mm}$ ).

Other material: 5 specimens, WMNH-2015-INV-139-143 (MOT, 21 May 2015); 30 specimens, WMNH-2015-INV155-184 (MOT, 17 June 2015); 3 specimens, WMNH-2015INV-483-485 (NIS, 29 October 2014); 224 specimens, WMNH-2015-INV-486-709 (MOT, 29 August 2015); 529 specimens, WMNH-2015-INV-868-1396 (MOT, 31 July 2015); 1 specimen, WMNH-2015-INV-1401 (MOT, 31 July 2015); 1 specimen, WMNH-2015-INV-1403 (MOT, 21 May 2015); 285 specimens, WMNH-2015-INV-1481-1765 (MOT, 29 September 2015); 1 specimen, WMNH-2016-INV-3 (MOT, 22 January 2016).

Description. Body small, anaesthetized length of largest specimen (WMNH-2016-INV-3) $13.0 \mathrm{~mm}$ (after preservation), cylindrical, slightly tapered toward posterior end (Fig. 1A, Table 1). Body colour (of preserved specimens) translucent, white to pink, sometimes greyish. Living specimens translucent orange. Mouth anterior; anus posterior. Oral disc inclined toward ventral side.

Ten tentacles non-retractile, slender, with smooth or, rarely, bumpy skin. Each tentacle with one pair of digits; sensory cups absent (Fig. 2A). Colour of tentacles white to whitish-pink (preserved specimens), sometimes greyish. Calcareous ring composed of five radial and five inter-radial plates, these all being thin and weak, with distally flattened ginglymus ends (Fig. 3A). Polian vesicle single (Table 1). Stone canal undiscovered. Two long and unbranched tubules of ovaries, and one or two long, unbranched tubules of testis present. Testis tubules shorter than ovary tubules. One ambiguous row of ciliated funnels situated in inter-radius of middle to posterior body cavity, near right side of mid-ventral longitudinal muscle.

Body wall containing wheel and sigmoid-hook ossicles (Figs 4A, 5A, 6, Table 2). Wheel ossicles rounded-hexagonal with six spokes. Inner margin of rim not parallel to outer margin, and rim narrower at corners. Teeth sharp but short, $7-16$ per radiant (means of $10-13$ in different specimens); often reduced in number and size at corners, but with no discontinuities in tooth series there. Spokes broad, their breadth amounting to $18-29 \%$ of wheel ossicle diameter (means 22-26\%) (Fig. 6). Wheel ossicles scattered sparsely in ventral inter-radial body wall, dense in anterior and posterior inter-radial body wall. Wheel ossicle aggregations (wheel papillae) absent. Wheel ossicle diameter $52-81 \mu \mathrm{m}$ (means $63-71 \mu \mathrm{m}$ ) in anterior dorsal side, $59-79 \mu \mathrm{m}$ (means $62-70 \mu \mathrm{m}$ ) in anterior ventral side, $50-78 \mu \mathrm{m}$ (means $55-70 \mu \mathrm{m}$ ) in posterior dorsal side, and $55-70 \mu \mathrm{m}$ (means $61-64 \mu \mathrm{m})$ in posterior ventral side, differing significantly among specimens (Kruskal-Wallis test, $P_{\mathbf{s}}<0.05$ ) in anterior dorsal and ventral sides and posterior dorsal side but not in posterior ventral side. Wheel ossicle diameter in two fully checked specimens (WMNH-2015-INV-1456, BIK-ECTC200) significantly different among these four body parts (Kruskal-Wallis test, $P_{\mathbf{S}}<0.05$ ), but not in third specimen (BIK-EC-201).

Sigmoid-hook ossicles in body wall arranged in two single rows in inter-radii, along both sides of longitudinal muscles, with pointed end facing toward inter-radius and blunt end facing toward longitudinal muscles (Fig. 4A). Outer edge of bend without minute teeth (Fig. 6). Shank broadest at bend, its length $65-84 \mu \mathrm{m}$ (means of $74-82 \mu \mathrm{m}$ in different specimens) in anterior dorsal side, $75-85 \mu \mathrm{m}$ (means $76-81 \mu \mathrm{m}$ ) in anterior ventral side, $61-75 \mu \mathrm{m}$ (means $64-70 \mu \mathrm{m}$ ) in posterior dorsal side, and 54-71 $\mu \mathrm{m}$ (means $64-69 \mu \mathrm{m}$ ) in posterior ventral side. Shank length of sigmoid-hooks significantly different among specimens (Kruskal-Wallis test, $P_{S}<0.05$ ) in anterior dorsal side and posterior dorsal and ventral sides but not in anterior ventral region (Table 2). Shank length in all three fully checked specimens significantly different among four body parts (Kruskal-Wallis test, $P_{\mathrm{s}}<0.05$ ).

Tentacles containing rod ossicles (Figs 5A, 6, Table 3), these spinous, most branching distally but lacking branches elsewhere. Rod ossicle length $37-74 \mu \mathrm{m}$, means of $55-64 \mu \mathrm{m}$ in different specimens, significantly different among them (Kruskal-Wallis test, $P<0.01$ ) (Table 3).

Distribution. In sandy-gravel sediment in calm inlets along the Pacific coast of Wakayama and Kochi Prefectures, Japan.

Etymology. The specific name mijim, a noun in apposition, is derived from the Japanese word meaning "particle".

DNA barcode sequence. A $650 \mathrm{bp}$ sequence of the mitochondrial $\mathrm{CO} 1$ gene was obtained from a paratype specimen (WMNH-2015-INV-1402, GenBank accession number LC152965). Base frequency was $A=19.1 \%, C=14.5 \%$, $\mathrm{G}=22.8 \%, \mathrm{~T}=43.7 \%$.

Genus Rowedota O'Loughlin and VandenSpiegel, 2010

Rowedota chippiru sp. nov.

(Figs 1B, 2B, 3B, 4B, 5B, 7)

Material examined. Holotype: WMNH-2015-INV1476 (ARA, 14 September 2015) (length $10.8 \mathrm{~mm}$, width $0.8 \mathrm{~mm}$ ). Paratypes: WMNH-2015-INV-1477 (ARA, 14 September 2015) (length $6.3 \mathrm{~mm}$, width $0.5 \mathrm{~mm}$ ); WMNH2015-INV-1478 (ARA, 14 September 2015) (length $3.6 \mathrm{~mm}$, width $0.4 \mathrm{~mm}$ ); WMNH-2015-INV-1479 (ARA, 14 September 2015) (length $9.2 \mathrm{~mm}$, width $0.7 \mathrm{~mm}$ ); WMNH2015-INV-1480 (ARA, 14 September 2015) (length $6.6 \mathrm{~mm}$, width $0.6 \mathrm{~mm})$. 

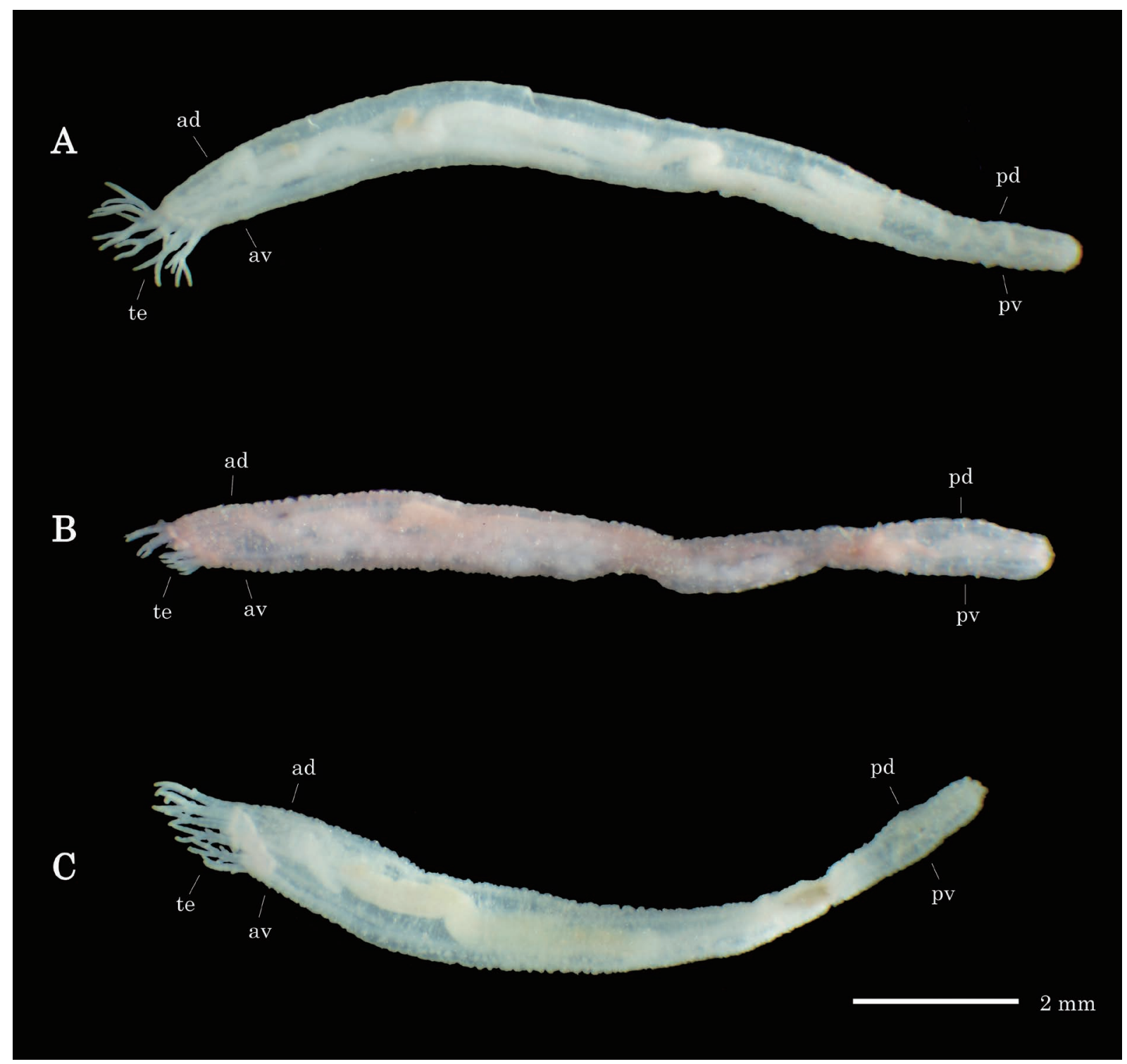

Fig. 1. Lateral views of Taeniogyrus mijim sp. nov. (holotype, WMNH-2015-INV-1457) (A); Rowedota chippiru sp. nov. (holotype, WMNH-2015-INV-1476) (B); and R. motoshimaensis sp. nov. (holotype, WMNH-2015-INV-1767) (C). Abbreviations: ad, anterior dorsal; av, anterior ventral; pd, posterior dorsal; pv, posterior ventral; te, tentacle.

Description. Body small, anaesthetized length of largest specimen (WMNH-2015-INV-1476) $10.8 \mathrm{~mm}$ (after preservation), cylindrical, slightly tapered toward posterior end (Fig. 1B, Table 1). Body colour (in preserved and living specimens) transparent white to greyish-pink. Mouth anterior; anus posterior. Oral disc inclined toward ventral side.

Ten tentacles non-retractile, slender, with bumpy skin. Each tentacle with one pair of digits; sensory cups absent (Fig. 2B). Colour of tentacles white to pink (in preserved specimens). Calcareous ring composed of five radial and five inter-radial plates, these all broad with distally flattened ginglymus ends (Fig. 3B). Polian vesicle single (Table 1). Stone canal undiscovered. Two long and unbranched tubules of ovaries; testis not observed. One ambiguous row of ciliated funnels situated in inter-radius of middle to posterior body cavity, near right side of mid-ventral longitudinal muscle.

Body wall containing wheel, sigmoid-hook, and thick-rod ossicles (Figs 4B, 5B, 7, Table 2). Wheel ossicles roundedhexagonal with six spokes. Inner margin of rim not parallel to outer margin, and rim narrower at corners. Teeth blunt, trapezoidal, 7-15 per radiant (means of 9-12 in different specimens), discontinuous at slight concavities of rim at corners. Spokes not broad, their breadth amounting to $11-21 \%$ of diameter (means 11-19\%) (Fig. 7). Wheel ossicles scattered sparsely in ventral inter-radial body wall but clearly arranged in longitudinal row in anterior ventral region. Wheel ossicle aggregations (wheel papillae) absent. Wheel ossicle diameter varying widely even in same tissue sample: $44-109 \mu \mathrm{m}$ (means $61-79 \mu \mathrm{m}$ ) in anterior dorsal side, $49-88 \mu \mathrm{m}$ (means $59-83 \mu \mathrm{m}$ ) in anterior ventral side, $45-86 \mu \mathrm{m}$ (means $54-66 \mu \mathrm{m}$ ) in posterior dorsal side, and $46-87 \mu \mathrm{m}$ (means $54-60 \mu \mathrm{m}$ ) in posterior ventral side. Wheel ossicle diameter in anterior dorsal side significantly different among five specimens (Kruskal-Wallis test, $P<0.05$ ) but not in other body wall parts among three fully 

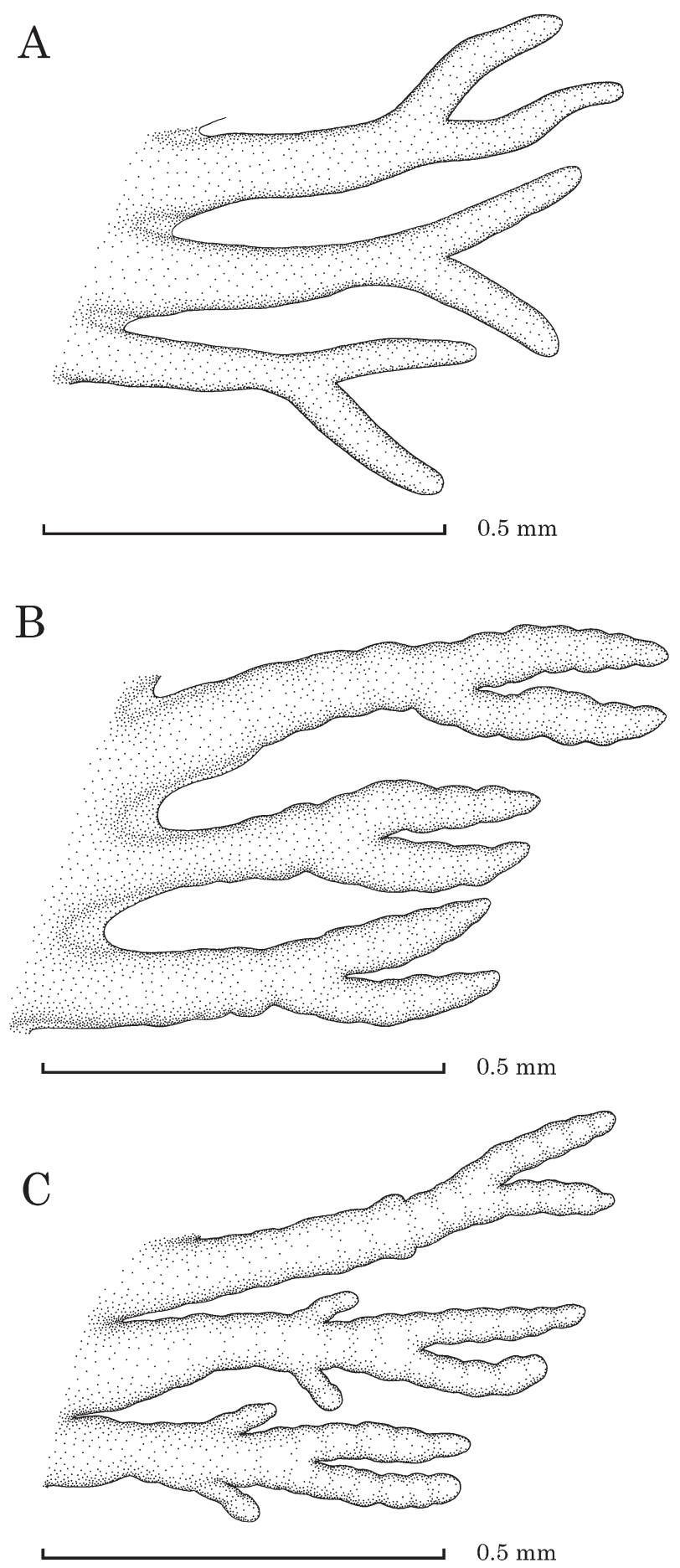

Fig. 2. Three left-side tentacles of Taeniogyrus mijim sp. nov. (holotype, WMNH-2015-INV-1457) (A); Rowedota chippiru sp. nov. (paratype, WMNH-2015-INV-1480) (B); and R. motoshimaensis sp. nov. (holotype, WMNH-2015-INV-1767) (C); all viewed from right side with dorsal side above.

checked specimens (Table 2). In two of latter specimens (WMNH-2015-INV-1477, -1479), wheel ossicle diameter significantly different among four body parts (KruskalWallis test, $P s<0.05$ ), but not in third specimen (WMNH2015-INV-1480).

Sigmoid-hook ossicles thick and large, arranged in single rows in inter-radii along both sides of longitudinal muscles, with pointed end facing toward inter-radius and blunt end facing toward longitudinal muscles. Outer edge of bend with 2-5 minute teeth. Shank broadest at bend, suddenly narrower distal to bend. Shank length $71-110 \mu \mathrm{m}$ (means $75-101 \mu \mathrm{m}$ ) in anterior dorsal side, $71-100 \mu \mathrm{m}$ (means $76-92 \mu \mathrm{m}$ ) in anterior ventral side, $57-81 \mu \mathrm{m}$ (means $66-77 \mu \mathrm{m}$ ) in posterior dorsal side, and $51-77 \mu \mathrm{m}$ (means $55-72 \mu \mathrm{m})$ in posterior ventral side. Shank length significantly different among five specimens in anterior dorsal part and among three specimens in other parts (Kruskal-Wallis test, $P \mathbf{s}<0.05$ ) (Table 2). Shank length significantly different among four body parts in two fully checked specimens (WMNH-2015-INV-1477, -1479) (Kruskal-Wallis test, $P s<0.05)$, but not in other one (WMNH-2015-INV-1480).

Thick-rod ossicles arc-shaped, distally blunt, with approximately 10-40 minute verrucae, arranged between wheel ossicles and sigmoid-hook ossicles. Length of thick-rod ossicles $64-79 \mu \mathrm{m}$ (means of $68-73 \mu \mathrm{m}$ in different specimens) in anterior dorsal side, $55-79 \mu \mathrm{m}$ (means $63-71 \mu \mathrm{m}$ ) in anterior ventral side, $51-57 \mu \mathrm{m}$ (means $52-55 \mu \mathrm{m}$ ) in posterior dorsal side, and $47-59 \mu \mathrm{m}$ (means $50-54 \mu \mathrm{m}$ ) in posterior ventral side. Length of thick-rod ossicles in anterior ventral side significantly different among three specimens (KruskalWallis test, $P<0.05)$ but not those of anterior dorsal side among five specimens and posterior ventral side among three specimens (Table 2); posterior dorsal side not analysed statistically as thick-rod ossicles very rare. Length of thick-rod ossicles in two fully checked specimens (WMNH2015-INV-1479, -1480) significantly different among four body wall parts (Kruskal-Wallis test, $P$ s $<0.01$ ) (Table 2); other fully checked specimen (WMNH-2015-INV-1477) not analysed due to its near lack of thick-rod ossicles in posterior dorsal side.

Tentacles containing rod ossicles (Figs 5B, 7, Table 3 ), these spinous with low number of branches, length $41-78 \mu \mathrm{m}$, means $51-68 \mu \mathrm{m}$ in five specimens, significantly different among them (Kruskal-Wallis test, $P<0.01$ ) (Table 3).

Distribution. In sand in lower intertidal zone of calm beach, Araha Beach, Okinawa Prefecture, southern Japan.

Etymology. The specific name chippiru, a noun in apposition, is derived from a Ryukyuan word for "something that is small".

DNA barcode sequence. A $650 \mathrm{bp}$ sequence of the mitochondrial $\mathrm{CO} 1$ gene was obtained from a paratype specimen (WMNH-2015-INV-1479, GenBank accession number LC152967). Base frequency was $A=16.3 \%, C=14.2 \%$, $\mathrm{G}=24.2 \%, \mathrm{~T}=45.4 \%$.

\section{Rowedota motoshimaensis sp. nov.} (Figs 1C, 2C, 3C, 4C, 5C, 8)

Material examined. Holotype: WMNH-2015-INV-1767 (MOT, 29 September 2015) (length $9.6 \mathrm{~mm}$, width $0.8 \mathrm{~mm}$ ). Paratypes: WMNH-2015-INV-710 (MOT, 29 August 2015) (length $5.6 \mathrm{~mm}$, width $0.7 \mathrm{~mm}$ ); WMNH-2015-INV-711 (MOT, 29 August 2015) (length $11.7 \mathrm{~mm}$, width $1.2 \mathrm{~mm}$ ); WMNH-2015-INV-715 (MOT, 29 August 2015) (length 


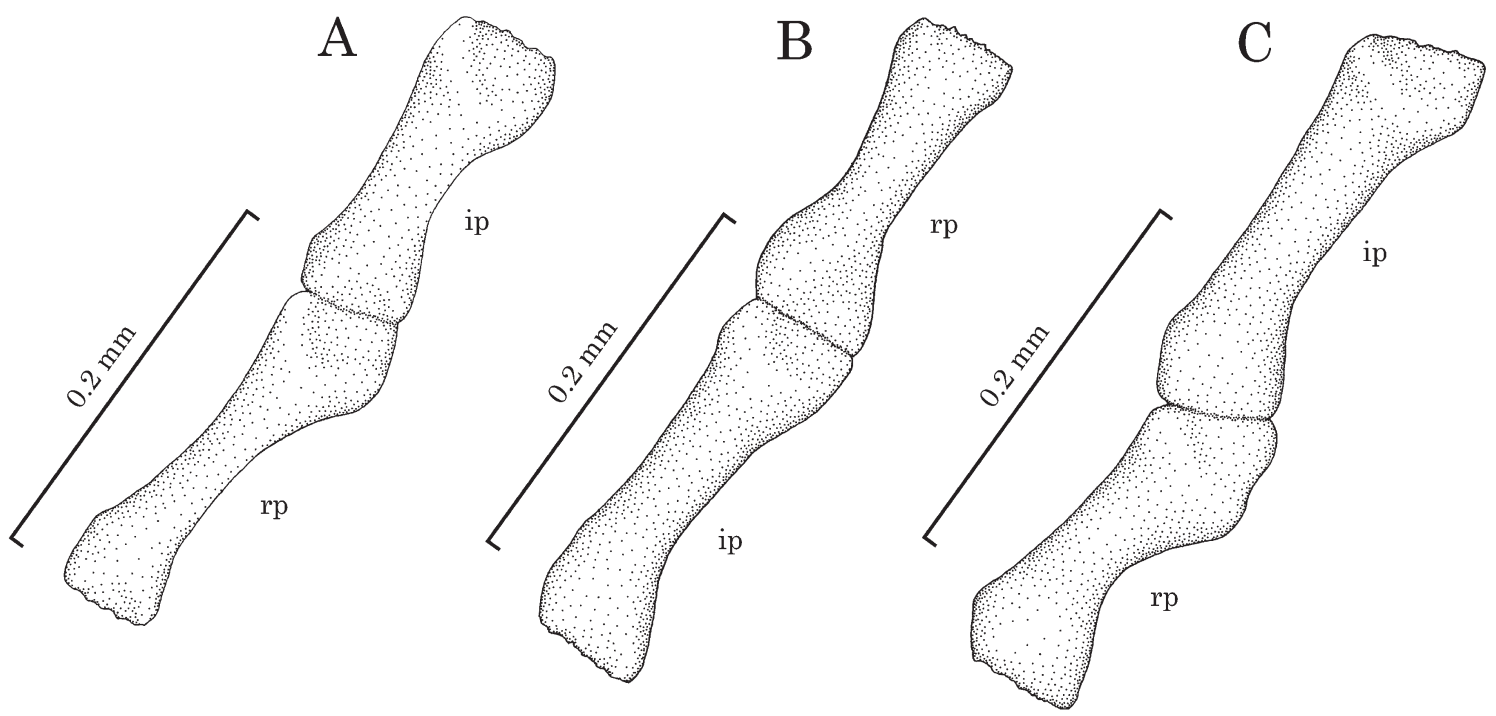

Fig. 3. One radial and one inter-radial plate each of calcareous ring of right side of Taeniogyrus mijim sp. nov. (paratype, WMNH2015-INV-1456) (A); Rowedota chippiru sp. nov. (paratype, WMNH-2015-INV-1479) (B); and R. motoshimaensis sp. nov. (paratype, WMNH-2015-INV-715) (C); all viewed from right side with dorsal side above. Abbreviations: ip, inter-radial plate; rp, radial plate.

Table 1. Summary of measurements and counts for five specimens each of the new species of Taeniogyrus and Rowedota.

\begin{tabular}{|c|c|c|c|c|c|c|c|c|c|c|}
\hline \multirow{2}{*}{ Registration No. ${ }^{a}$} & \multirow{2}{*}{$\begin{array}{l}\text { Type } \\
\text { status }\end{array}$} & \multirow{2}{*}{ Locality $^{\mathrm{b}}$} & \multirow{2}{*}{$\begin{array}{c}\text { Date of } \\
\text { collection }\end{array}$} & \multirow{2}{*}{$\begin{array}{l}\text { Anaesthetized } \\
(+) \text { or not }(-)\end{array}$} & \multicolumn{2}{|c|}{ Body size $(\mathrm{mm})$} & \multicolumn{3}{|c|}{ Counts } & \multirow{2}{*}{ Gonad type } \\
\hline & & & & & Length & Width & Tentacles & Tentacle digits & Polian vesicles & \\
\hline \multicolumn{11}{|l|}{ T. mijim sp. nov. } \\
\hline WMNH-2015-INV-1402 & paratype & MOT & 31 July 2015 & + & 7.2 & 0.7 & 10 & 2 & 1 & hermaphroditic \\
\hline WMNH-2015-INV-1456 & paratype & MOT & 17 June 2015 & + & 9.4 & 1.0 & 10 & 2 & 1 & hermaphroditic \\
\hline WMNH-2015-INV-1457 & holotype & MOT & 17 June 2015 & + & 11.2 & 1.0 & 10 & 2 & 1 & hermaphroditic \\
\hline BIK-EC-T0200 & paratype & NIS & 29 October 2014 & - & 6.0 & 0.4 & 10 & 2 & 1 & hermaphroditic \\
\hline BIK-EC-T0201 & paratype & NIS & 29 October 2014 & - & 8.5 & 0.9 & 10 & 2 & 1 & hermaphroditic \\
\hline \multicolumn{11}{|l|}{ R. chippiru sp. nov. } \\
\hline WMNH-2015-INV-1476 & holotype & ARA & 14 September 2015 & + & 10.8 & 0.8 & 10 & 2 & 1 & ovary \\
\hline WMNH-2015-INV-1477 & paratype & ARA & 14 September 2015 & + & 6.3 & 0.5 & 10 & 2 & 1 & ovary \\
\hline WMNH-2015-INV-1478 & paratype & ARA & 14 September 2015 & + & 3.6 & 0.4 & 10 & 2 & 1 & immature \\
\hline WMNH-2015-INV-1479 & paratype & ARA & 14 September 2015 & + & 9.2 & 0.7 & 10 & 2 & 1 & ovary \\
\hline WMNH-2015-INV-1480 & paratype & ARA & 14 September 2015 & + & 6.6 & 0.6 & 10 & 2 & 1 & ovary \\
\hline \multicolumn{11}{|l|}{ R. motoshimaensis sp. nov. } \\
\hline WMNH-2015-INV-710 & paratype & MOT & 29 August 2015 & + & 5.6 & 0.7 & 10 & 4 & 1 & immature \\
\hline WMNH-2015-INV-711 & paratype & MOT & 29 August 2015 & + & 11.7 & 1.2 & 10 & 4 & 1 & ovary \\
\hline WMNH-2015-INV-715 & paratype & MOT & 29 August 2015 & - & 9.5 & 0.8 & 10 & $3-4$ & 1 & testis \\
\hline WMNH-2015-INV-1400 & paratype & MOT & 31 July 2015 & - & 7.6 & 1.0 & 10 & 2 & 1 & immature \\
\hline WMNH-2015-INV-1767 & holotype & MOT & 29 September 2015 & + & 9.6 & 0.8 & 10 & $2-4$ & 1 & testis \\
\hline
\end{tabular}

${ }^{a}$ WMNH-INV: Invertebrate Collection of the Wakayama Prefectural Museum of Natural History, BIK-EC: Echinodermata Collection of the Biological Institute of Kuroshio. ${ }^{b}$ MOT: Motoshima Islet, Mera, Tanabe, Wakayama, NIS: Nishidomari, Otsuki, Kochi, ARA: Araha Beach, Chatan, Okinawa.

$9.5 \mathrm{~mm}$, width $0.8 \mathrm{~mm}$ ); WMNH-2015-INV-1400 (MOT, 31 July 2015) (length $7.6 \mathrm{~mm}$, width $1.0 \mathrm{~mm}$ ).

Other material: 3 specimens, WMNH-2015-INV-712-714 (MOT, 29 August 2015); 2 specimens, WMNH-2015-INV1397, 1398 (MOT, 31 July 2015); 1 specimen, WMNH-2015INV-1404 (MOT, 21 May 2015); 1 specimen, WMNH-2015INV-1455 (MOT, 17 June 2015); 1 specimen, WMNH-2015INV-1766 (MOT, September 2015); 2 specimens, WMNH2016-INV-1, 2 (MOT, 22 January 2016).

Description. Body small, anaesthetized length of largest type specimen (WMNH-2015-INV-711) $11.7 \mathrm{~mm}$ (after preservation), cylindrical, slightly tapered toward posterior end (Fig. 1C, Table 1). Body colour (in preserved and liv- ing specimens) white to light brown, not very transparent. Mouth anterior; anus posterior. Oral disc inclined toward ventral side.

Ten tentacles non-retractile, slender, with bumpy skin. Each tentacle with two pairs of digits; sensory cups absent; distal two digits longer than subdistal two digits (Fig. 2C). Subdistal digits sometimes absent from individual tentacles. Colour of tentacles white (in preserved specimens). Calcareous ring composed of five radial and five inter-radial plates, these all thin and weak, with distally flattened ginglymus ends (Fig. 3C). Polian vesicle single (Table 1). Stone canal undiscovered. Male and female systems observed in different specimens, both ovary and testis consisting of two long, 


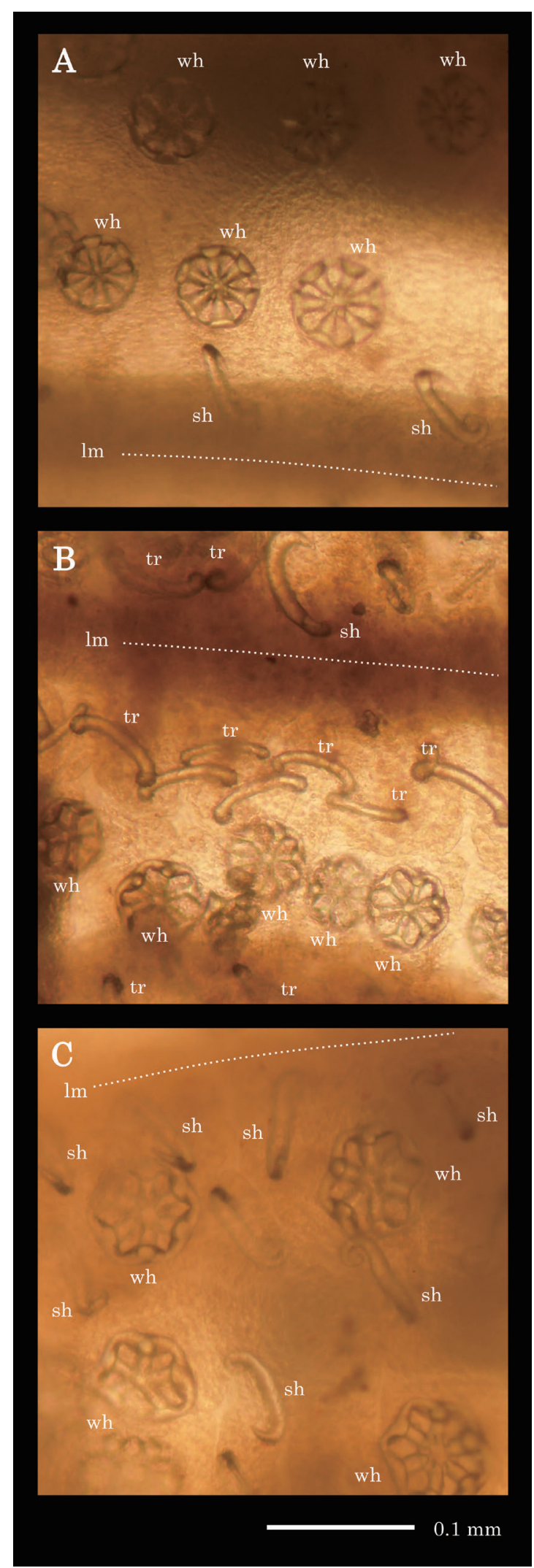

Fig. 4. Microphotograph of anterior ventral skin containing ossicles of Taeniogyrus mijim sp. nov. (holotype, WMNH2015-INV-1457) (A); Rowedota chippiru sp. nov. (holotype, WMNH-2015-INV-1476) (B); and R. motoshimaensis sp. nov. (holotype, WMNH-2015-INV-1767) (C); all in preserved state following fixation with anaesthesia. Abbreviations: $1 \mathrm{~m}$, longitudinal muscle; sh, sigmoid-hook; tr, thick rod; wh, wheel. unbranched tubules. One ambiguous row of ciliated funnels situated in inter-radius of middle to posterior body cavity, near right side of mid-ventral longitudinal muscle.

Body wall containing wheel and sigmoid-hook ossicles (Figs 4C, 5C, 8, Table 2). Wheel ossicles rounded hexagonal with six spokes. Inner margin of rim not parallel to outer margin, and rim narrower at corners. Teeth small and blunt, mostly semi-circular, 8-21 per radiant (means of 11-19 in different specimens), discontinuous at concavities of rim at corners. Spokes not broad, their breadth amounting to $14-23 \%$ of diameter (means 16-22\%) (Fig. 8). Wheel ossicles scattered sparsely in ventral inter-radial body-wall. Wheel ossicle aggregations (wheel papillae) absent. Wheel ossicle diameter varying widely even in same tissue sample: $61-133 \mu \mathrm{m}$ (means $84-103 \mu \mathrm{m}$ ) in anterior dorsal side, 56-110 $\mu \mathrm{m}$ (means $70-95 \mu \mathrm{m}$ ) in anterior ventral side, 56$107 \mu \mathrm{m}$ (means $81-85 \mu \mathrm{m}$ ) in posterior dorsal side, and 53$103 \mu \mathrm{m}$ (means $70-75 \mu \mathrm{m}$ ) in posterior ventral side. Wheel ossicle diameter in anterior dorsal side significantly different among five specimens (Kruskal-Wallis test, $P<0.05$ ), but not in other parts among three fully checked specimens (Table 2). In two of latter specimens (WMNH-2015-INV-711, -715), wheel ossicle diameter significantly different among four body wall parts (Kruskal-Wallis test, $P s<0.05$ ), but not in third specimen (WMNH-2015-INV-710).

Sigmoid-hook ossicles thick and large, arranged in single rows in inter-radii along both sides of longitudinal muscles, with pointed end facing toward inter-radius and blunt end facing toward longitudinal muscles. One to three additional ambiguous rows of sigmoid-hook ossicles scattered in inter-radii, facing different ways. Outer edge of bend without minute teeth (Fig. 8). Shank broadest on proximal side of bend, and gradually thinning through bend. Shank length $70-104 \mu \mathrm{m}$ (means of $78-95 \mu \mathrm{m}$ in different specimens) in anterior dorsal side, $73-96 \mu \mathrm{m}$ (means $75-91 \mu \mathrm{m}$ ) in anterior ventral side, $61-93 \mu \mathrm{m}$ (means $74-85 \mu \mathrm{m}$ ) in posterior dorsal side, and $61-94 \mu \mathrm{m}$ (means $71-82 \mu \mathrm{m}$ ) in posterior ventral side. Shank length significantly different among five specimens in anterior dorsal part and among three specimens in other parts (Kruskal-Wallis test, $P_{\mathrm{s}}<0.05$ ) (Table 2). Shank length in each of latter three specimens significantly different among four body wall parts (Kruskal-Wallis test, $P$ s $<0.05)$.

Tentacles containing spinous rod ossicles (Figs 5C, 8, Table 3), most being branched distally and some with central branches. Length $37-88 \mu \mathrm{m}$, means $58-70 \mu \mathrm{m}$, significantly different among five specimens (Kruskal-Wallis test, $P<0.01$ ) (Table 3).

Distribution. In sandy-gravel sediment of lower intertidal zone in calm inlet along Pacific coast of Wakayama Prefecture, Japan.

Etymology. The specific name motoshimaensis is derived from the name of the type locality islet, Motoshima.

DNA barcode sequence. A $650 \mathrm{bp}$ sequence of the mitochondrial $\mathrm{CO} 1$ gene was obtained from a paratype specimen (WMNH-2015-INV-1400, GenBank accession number LC152968). Base frequency was $\mathrm{A}=16.8 \%, \mathrm{C}=13.8 \%$, $\mathrm{G}=24.8 \%, \mathrm{~T}=44.6 \%$. 

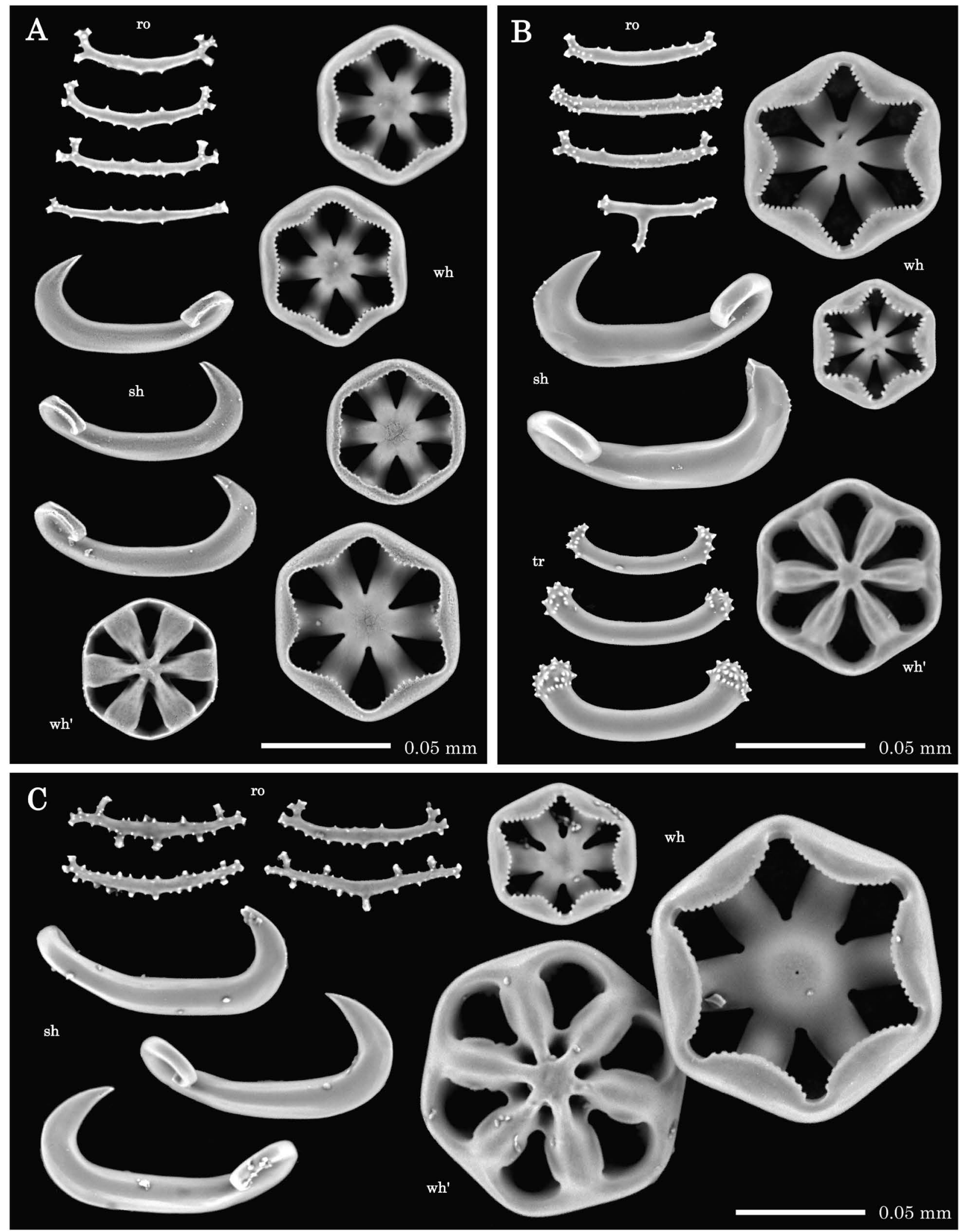

Fig. 5. SEM images of ossicles from a tentacle and anterior dorsal body wall of Taeniogyrus mijim sp. nov. (paratype, WMNH2015-INV-1456) (A); Rowedota chippiru sp. nov. (paratype, WMNH-2015-INV-1479) (B); and R. motoshimaensis sp. nov. (paratype, WMNH-2015-INV-715) (C). Abbreviations: ro, rod from tentacle; sh, sigmoid-hook from body wall; tr, thick rod from body wall; wh, wh', external and internal sides of wheel from body wall, respectively. 
A

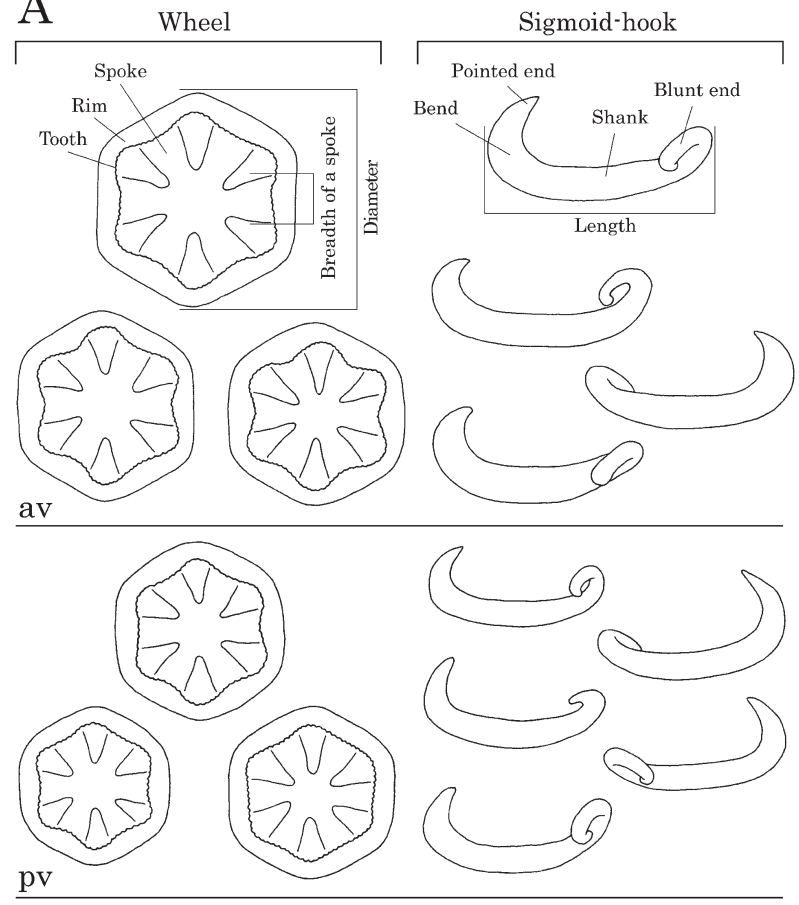

$\underline{\mathrm{pv}}$
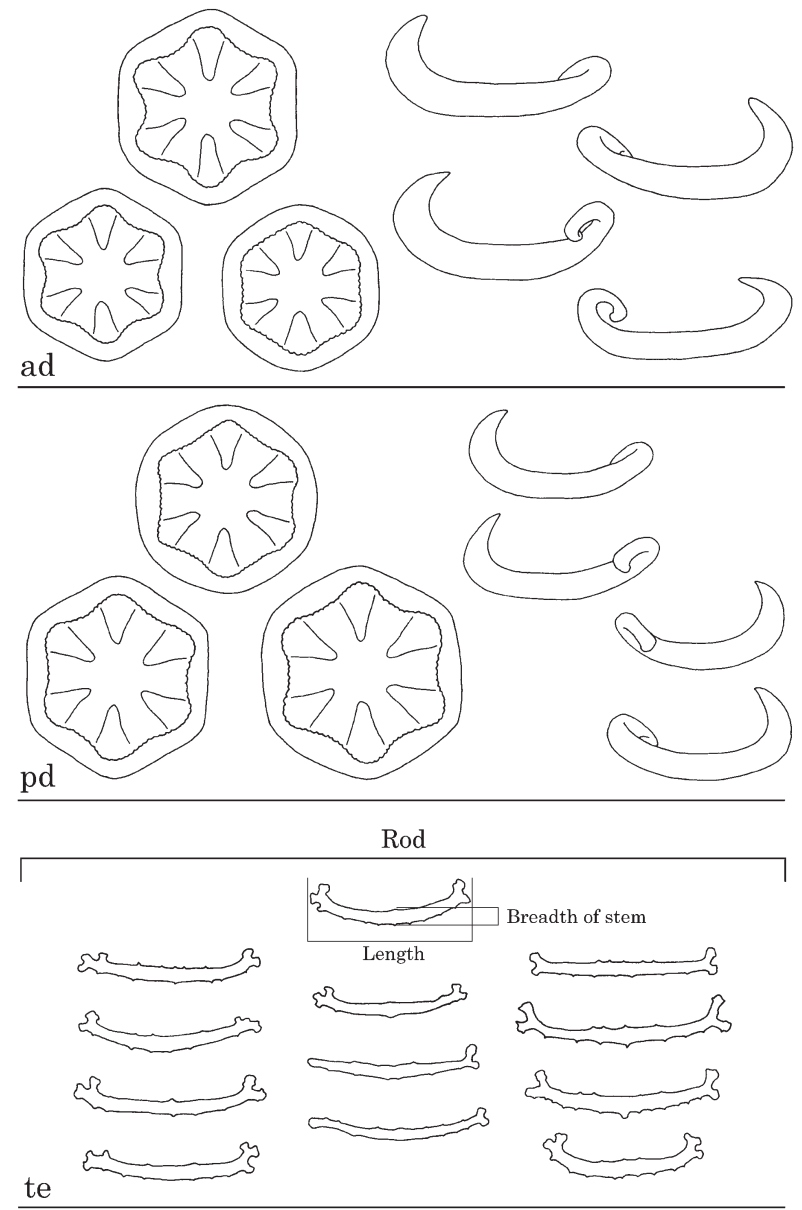

$\mathrm{B}$

Wheel

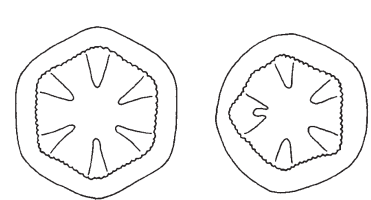

vas

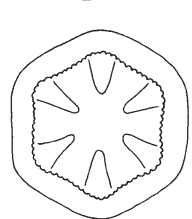

av
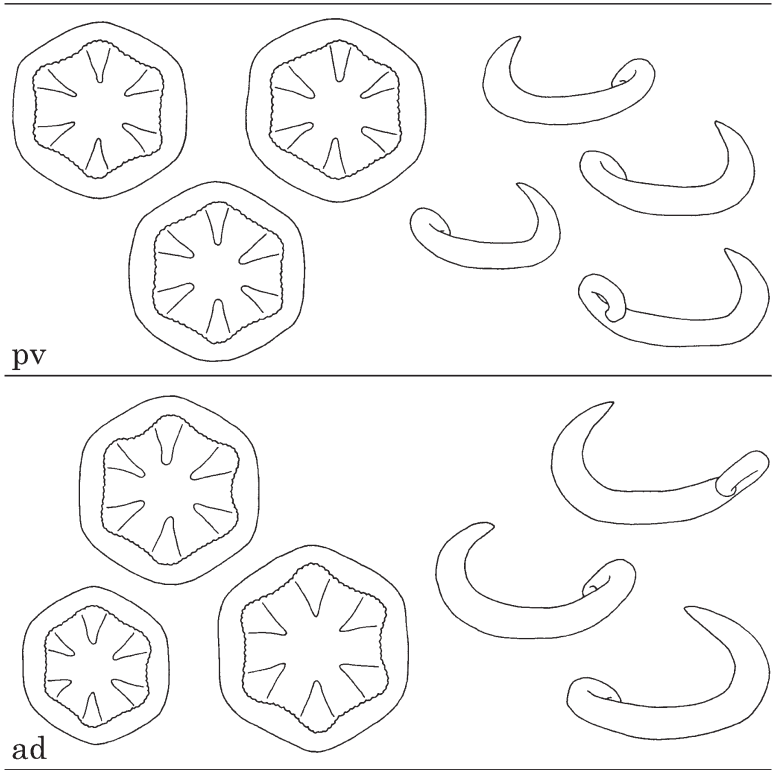

ad
Sigmoid-hook

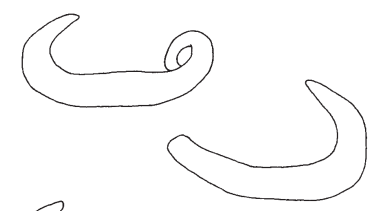

(6)

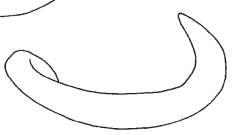

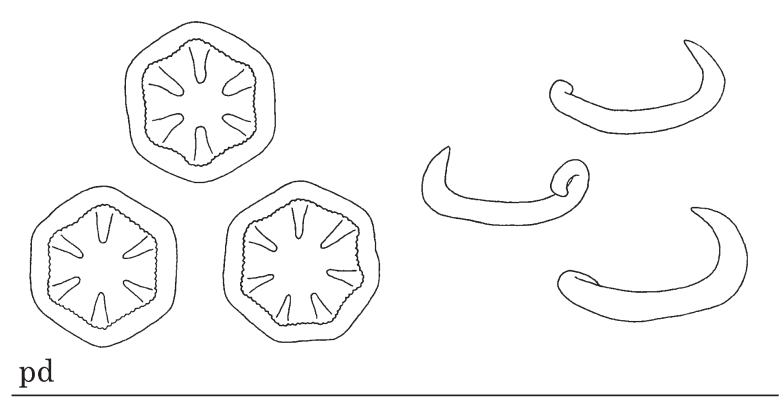

$\mathrm{pd}$

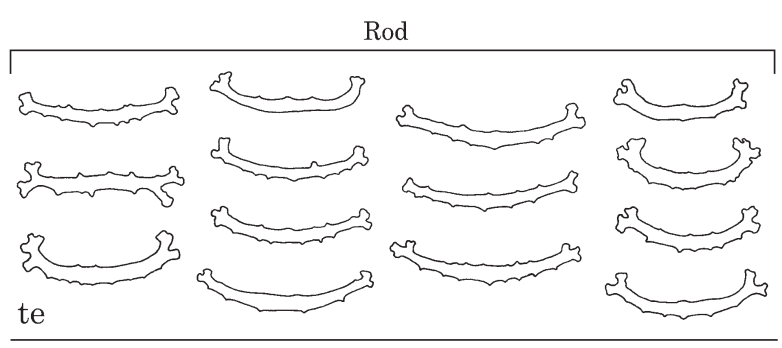

$0.05 \mathrm{~mm}$

Fig. 6. Taeniogyrus mijim sp. nov., ossicles from a tentacle and four parts of the body wall, and diagrams of their measurement axes, from WMNH-2015-INV-1456 (paratype) (A); and BIK-EC-T0200 (paratype) (B). Abbreviations: ad, anterior dorsal; av, anterior ventral; pd, posterior dorsal; pv, posterior ventral; te, tentacle. 


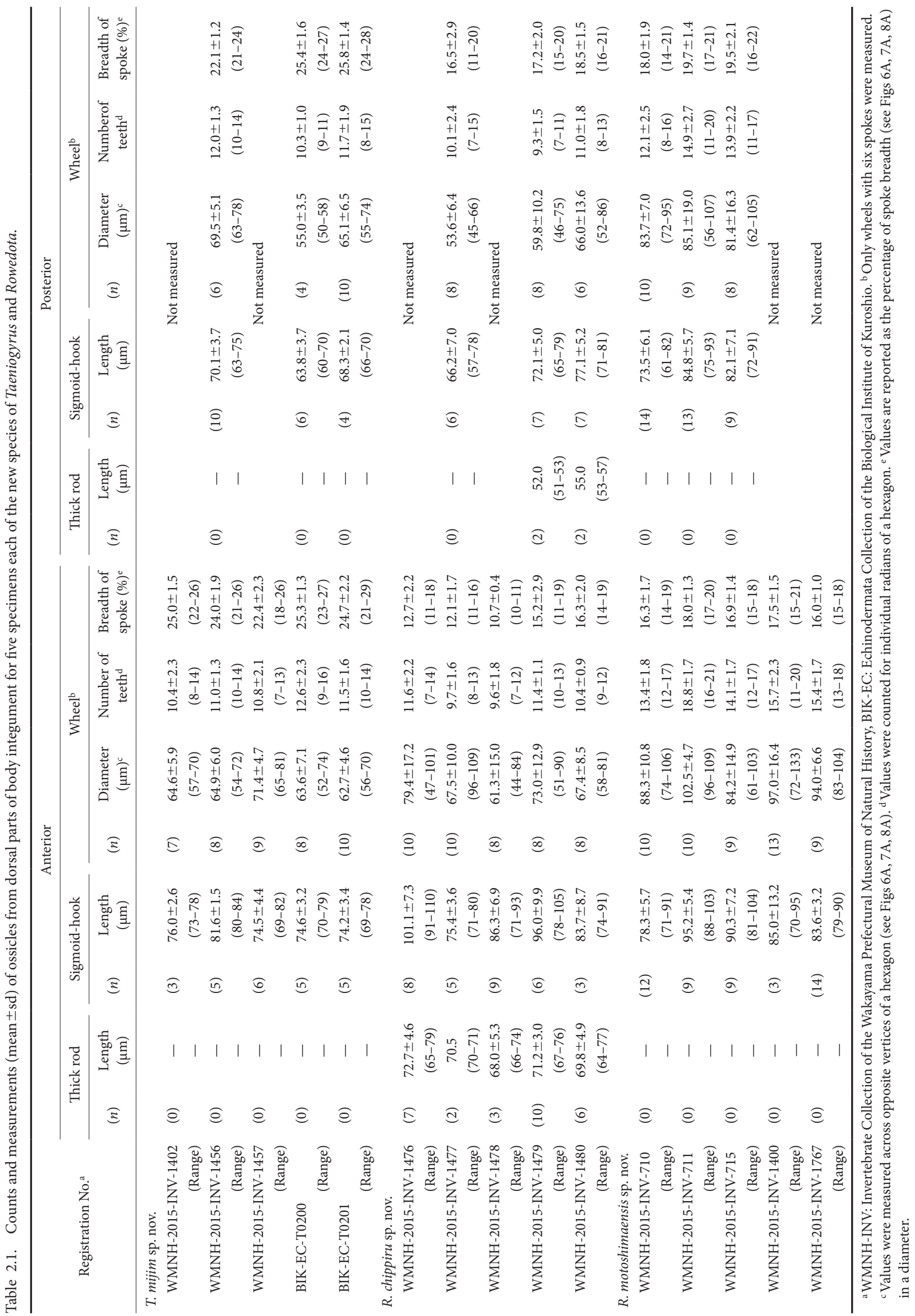




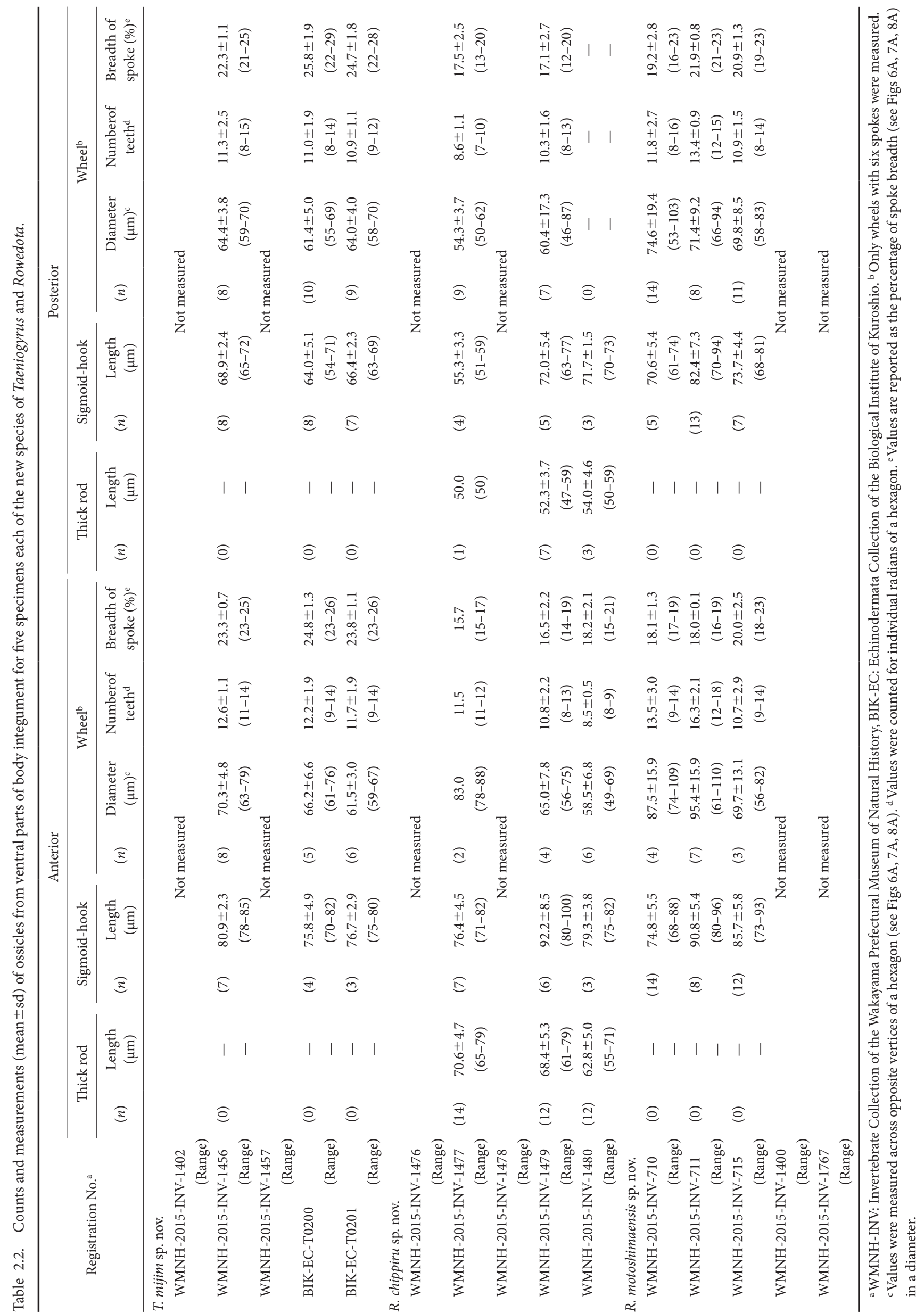


Table 3. Counts and measurements (mean \pm sd) of rod ossicles from tentacles of five specimens each of the new species of Taeniogyrus and Rowedota.

\begin{tabular}{|c|c|c|c|c|c|}
\hline \multirow{3}{*}{ Registration No. ${ }^{a}$} & \multicolumn{5}{|c|}{ Ossicles of tentacles } \\
\hline & \multirow{2}{*}{$(n)$} & \multirow{2}{*}{$\begin{array}{l}\text { Length } \\
(\mu \mathrm{m})\end{array}$} & \multirow{2}{*}{$\begin{array}{l}\text { Breadth of stem } \\
\qquad(\mu \mathrm{m})^{\mathrm{b}}\end{array}$} & \multicolumn{2}{|c|}{ Number of branches } \\
\hline & & & & Distally & Centrally \\
\hline \multicolumn{6}{|l|}{ T. mijim sp. nov. } \\
\hline $\begin{array}{r}\text { WMNH-2015-INV-1402 } \\
\text { (Range) }\end{array}$ & (12) & $\begin{array}{c}56.6 \pm 8.7 \\
(45-72)\end{array}$ & $\begin{array}{c}4.8 \pm 0.8 \\
(4-6)\end{array}$ & $\begin{array}{c}3.2 \pm 1.0 \\
(2-4)\end{array}$ & $\begin{array}{c}0 \\
(0)\end{array}$ \\
\hline $\begin{array}{r}\text { WMNH-2015-INV-1456 } \\
\text { (Range) }\end{array}$ & (10) & $\begin{array}{c}64.1 \pm 4.9 \\
(57-72)\end{array}$ & $\begin{array}{c}5.6 \pm 0.8 \\
(5-7)\end{array}$ & $\begin{array}{c}4.5 \pm 1.1 \\
(3-6)\end{array}$ & $\begin{array}{c}0.3 \pm 0.5 \\
(0-1)\end{array}$ \\
\hline $\begin{array}{r}\text { WMNH-2015-INV-1457 } \\
\text { (Range) }\end{array}$ & (11) & $\begin{array}{c}54.9 \pm 8.1 \\
(45-67)\end{array}$ & $\begin{array}{c}4.8 \pm 0.8 \\
(4-6)\end{array}$ & $\begin{array}{c}3.7 \pm 0.8 \\
(2-5)\end{array}$ & $\begin{array}{c}0.2 \pm 0.6 \\
(0-2)\end{array}$ \\
\hline $\begin{array}{l}\text { BIK-EC-T0200 } \\
\text { (Range) }\end{array}$ & (16) & $\begin{array}{c}58.1 \pm 8.7 \\
(47-74)\end{array}$ & $\begin{array}{c}5.7 \pm 1.2 \\
(4-8)\end{array}$ & $\begin{array}{c}5.3 \pm 1.4 \\
(3-7)\end{array}$ & $\begin{array}{c}0.1 \pm 0.3 \\
(0-1)\end{array}$ \\
\hline $\begin{array}{l}\text { BIK-EC-T0201 } \\
\text { (Range) }\end{array}$ & (10) & $\begin{array}{l}56.9 \pm 10.6 \\
(37-72)\end{array}$ & $\begin{array}{c}4.0 \pm 0.9 \\
(3-6)\end{array}$ & $\begin{array}{c}3.7 \pm 1.3 \\
(2-6)\end{array}$ & $\begin{array}{c}0 \\
(0)\end{array}$ \\
\hline \multicolumn{6}{|l|}{ R. chippiru sp. nov. } \\
\hline $\begin{array}{r}\text { WMNH-2015-INV-1476 } \\
\text { (Range) }\end{array}$ & (11) & $\begin{array}{c}67.5 \pm 7.0 \\
(55-78)\end{array}$ & $\begin{array}{r}7.2 \pm 1.3 \\
(5-10)\end{array}$ & $\begin{array}{c}2.3 \pm 0.6 \\
(2-4)\end{array}$ & $\begin{array}{c}0.1 \pm 0.3 \\
(0-1)\end{array}$ \\
\hline $\begin{array}{r}\text { WMNH-2015-INV-1477 } \\
\text { (Range) }\end{array}$ & (8) & $\begin{array}{c}58.0 \pm 5.3 \\
(51-64)\end{array}$ & $\begin{array}{c}4.5 \pm 0.5 \\
(4-5)\end{array}$ & $\begin{array}{c}2 \\
(2)\end{array}$ & $\begin{array}{c}0.1 \pm 0.4 \\
(0-1)\end{array}$ \\
\hline $\begin{array}{r}\text { WMNH-2015-INV-1478 } \\
\text { (Range) }\end{array}$ & (10) & $\begin{array}{c}55.1 \pm 2.8 \\
(51-61)\end{array}$ & $\begin{array}{l}5.3 \pm 0.7 \\
(4-6)\end{array}$ & $\begin{array}{c}2 \\
(2)\end{array}$ & $\begin{array}{c}0 \\
(0)\end{array}$ \\
\hline $\begin{array}{r}\text { WMNH-2015-INV-1479 } \\
\text { (Range) }\end{array}$ & (11) & $\begin{array}{c}57.9 \pm 6.6 \\
(51-72)\end{array}$ & $\begin{array}{c}5.3 \pm 0.9 \\
(4-7)\end{array}$ & $\begin{array}{c}2.1 \pm 0.3 \\
(2-3)\end{array}$ & $\begin{array}{c}0.4 \pm 0.9 \\
(0-3)\end{array}$ \\
\hline $\begin{array}{r}\text { WMNH-2015-INV-1480 } \\
\text { (Range) }\end{array}$ & (11) & $\begin{array}{c}50.5 \pm 5.5 \\
(41-59)\end{array}$ & $\begin{array}{c}4.8 \pm 0.8 \\
(4-6)\end{array}$ & $\begin{array}{c}2.8 \pm 0.9 \\
(2-4)\end{array}$ & $\begin{array}{c}0.3 \pm 0.5 \\
(0-1)\end{array}$ \\
\hline \multicolumn{6}{|l|}{ R. motoshimaensis sp. nov. } \\
\hline $\begin{array}{r}\text { WMNH-2015-INV-710 } \\
\text { (Range) }\end{array}$ & (6) & $\begin{array}{c}65.5 \pm 7.7 \\
(54-73)\end{array}$ & $\begin{array}{c}5.2 \pm 2.1 \\
(3-9)\end{array}$ & $\begin{array}{c}2 \\
(2)\end{array}$ & $\begin{array}{l}1.7 \pm 2.0 \\
(0-4)\end{array}$ \\
\hline $\begin{array}{r}\text { WMNH-2015-INV-711 } \\
\text { (Range) }\end{array}$ & (11) & $\begin{array}{c}60.2 \pm 5.7 \\
(50-68)\end{array}$ & $\begin{array}{c}5.9 \pm 0.7 \\
(5-7)\end{array}$ & $\begin{array}{c}4.5 \pm 1.4 \\
(3-8)\end{array}$ & $\begin{array}{c}2.0 \pm 1.5 \\
(0-4)\end{array}$ \\
\hline $\begin{array}{r}\text { WMNH-2015-INV-715 } \\
\text { (Range) }\end{array}$ & (13) & $\begin{array}{c}58.4 \pm 9.7 \\
(37-69)\end{array}$ & $\begin{array}{l}5.1 \pm 0.6 \\
(4-6)\end{array}$ & $\begin{array}{c}3.0 \pm 1.2 \\
(2-6)\end{array}$ & $\begin{array}{c}1.3 \pm 1.4 \\
(0-4)\end{array}$ \\
\hline $\begin{array}{r}\text { WMNH-2015-INV-1400 } \\
\text { (Range) }\end{array}$ & (9) & $\begin{array}{c}66.7 \pm 9.2 \\
(55-81)\end{array}$ & $\begin{array}{c}5.8 \pm 1.0 \\
(4-7)\end{array}$ & $\begin{array}{c}3.9 \pm 1.8 \\
(2-6)\end{array}$ & $\begin{array}{c}1.1 \pm 1.3 \\
(0-3)\end{array}$ \\
\hline $\begin{array}{r}\text { WMNH-2015-INV-1767 } \\
\text { (Range) }\end{array}$ & (17) & $\begin{array}{l}69.6 \pm 11.2 \\
(42-88)\end{array}$ & $\begin{array}{c}4.8 \pm 0.9 \\
(3-6)\end{array}$ & $\begin{array}{c}3.2 \pm 1.0 \\
(2-5)\end{array}$ & $\begin{array}{c}1.6 \pm 1.7 \\
(0-5)\end{array}$ \\
\hline
\end{tabular}

a WMNH-INV: Invertebrate Collection of the Wakayama Prefectural Museum of Natural History, BIK-EC: Echinodermata Collection of the Biological Institute of Kuroshio. ${ }^{b}$ Values were measured near the center while ignoring any side branches (see Figs 6A, 7A, 8A).

\section{Discussion}

In Japan, four species of Taeniogyrus have been reported before now, and none of Rowedota: Taeniogyrus cidaridis Ohshima, 1914 from the Goto Islands, off Sagami Bay, and in the Uraga Strait (Ohshima 1914, 1915); T. misakiensis (Ohshima, 1919) from off Sagami Bay (Ohshima 1914, 1919); T. japonicus (Marenzeller, 1881) from Sagami Bay (Marenzeller 1882; Ohshima 1914) and several places in central and southern Japan (Utinomi 1965; Imaoka 1995); and T. roseus (Ohshima, 1914) from Okinawa (Ohshima 1914).

Among them, Taeniogyrus misakiensis was first mentioned, as Trochodota dunedinensis (Parker, 1881), by Ohshima (1914); Ohshima, however, pointed out some differences between his specimen from Japan and Parker's (1881)
New Zealand form of Tr. dunedinensis, and suggested that the former may be a distinct species. Afterwards, Ohshima (1919) did indeed propose Tr. misakiensis as a new species, and the name is available by indication because he cited his own (Ohshima 1914) previously published description of it as Tr. dunedinensis. Unfortunately, Ohshima's (1919) taxonomic act has been overlooked by all researchers to date, probably because that work was published in the Japanese language for the most part. Later, in a dichotomous key, Clark (1921) diagnosed a new species, Tr. diasema Clark, 1921 (currently Ta. diasemus), for Ohshima's (1914) supposed Tr. dunedinensis. This new species was based on the same single holotype specimen on which Ohshima's (1919) Tr. misakiensis had been based, but with no mention of the latter nominal species. Since Ohshima's (1919) report was published before 1931, his nomenclatural act is considered valid under Articles 11 and 12. 2. 1 of the International 
A

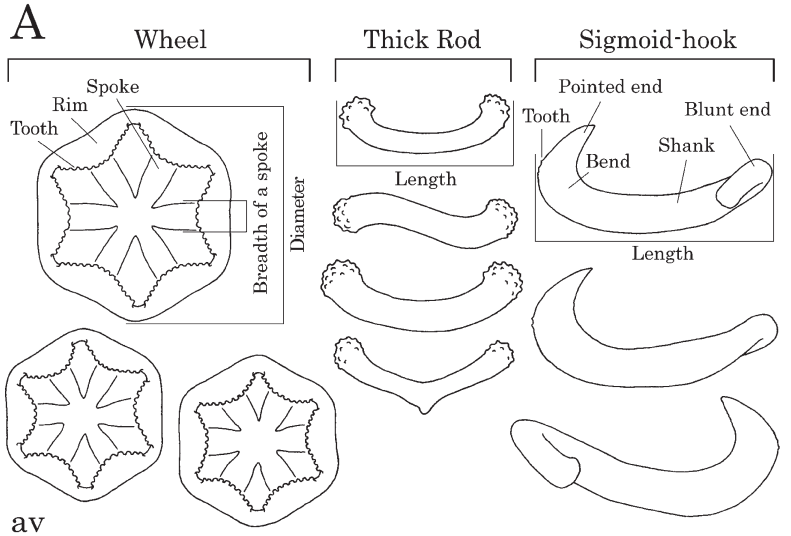

av

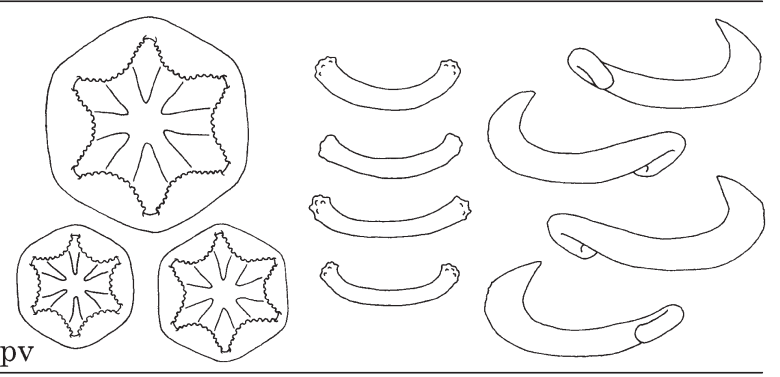

pv

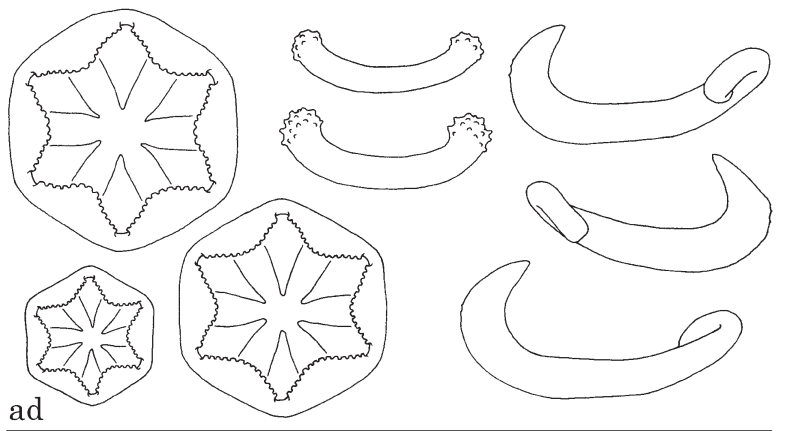

ad

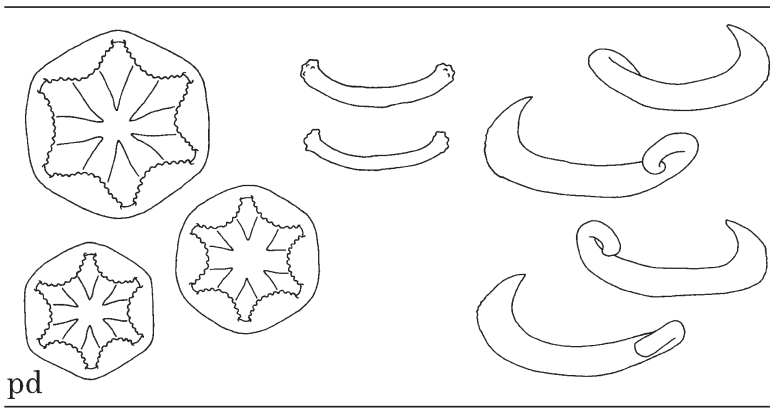

Rod

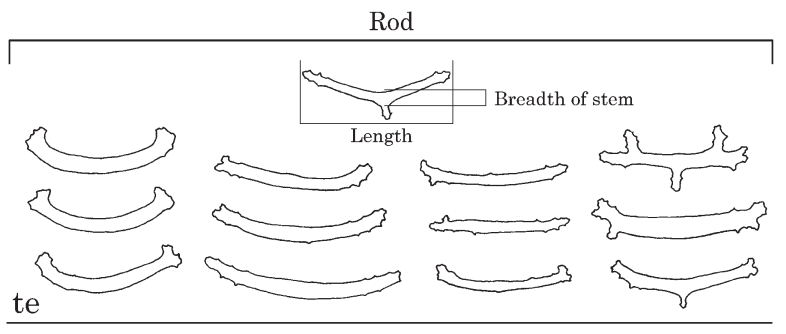

B

Wheel

Thick Rod $n$
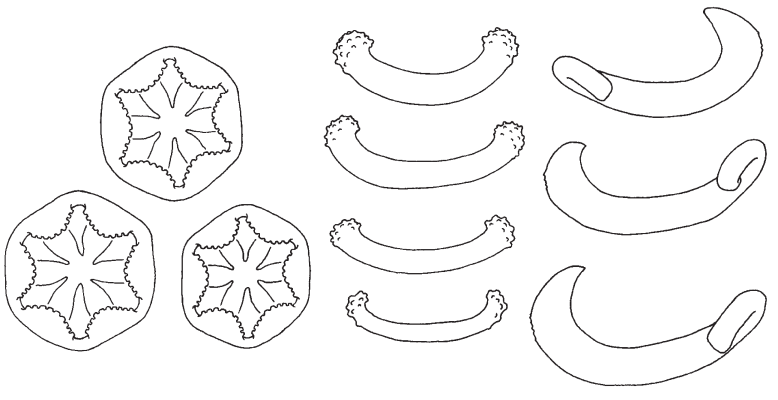

av

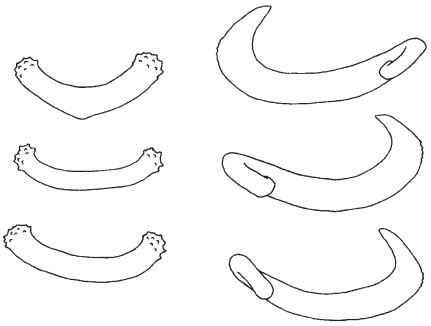

pv
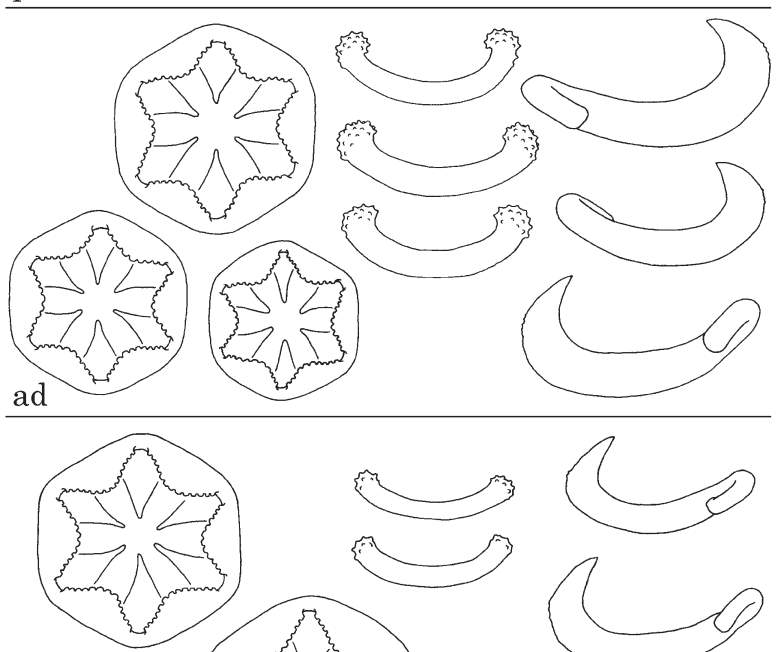

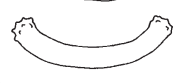
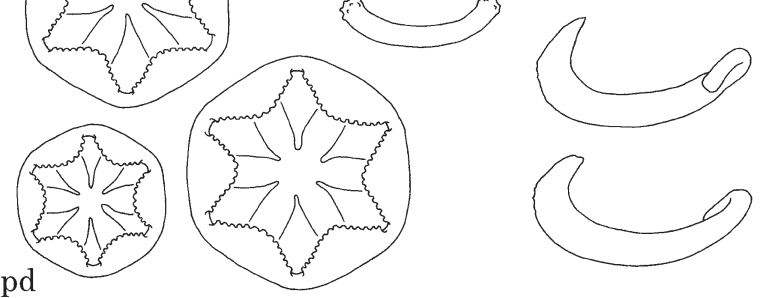

Rod

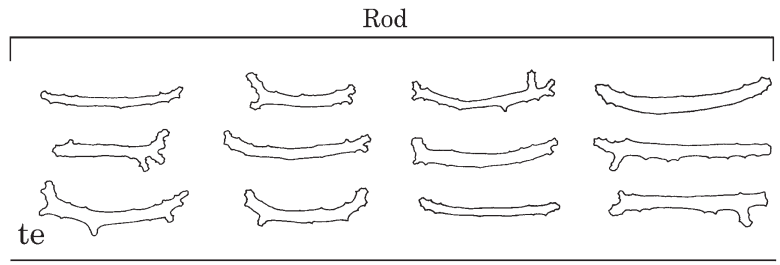

$0.05 \mathrm{~mm}$

Fig. 7. Rowedota chippiru sp. nov., ossicles from a tentacle and four parts of the body wall, and diagrams of their measurement axes, from WMNH-2015-INV-1479 (paratype) (A); and WMNH-2015-INV-1480 (paratype) (B). Abbreviations: ad, anterior dorsal; av, anterior ventral; pd, posterior dorsal; pv, posterior ventral; te, tentacle.

Code of Zoological Nomenclature (International Commission on Zoological Nomenclature 1999), and Ta. diasemus is judged to be a junior objective synonym of Ta. misakiensis, which has priority.

None of them agrees morphologically with any of the present three new species. In T. cidaridis, aggregations of 
A
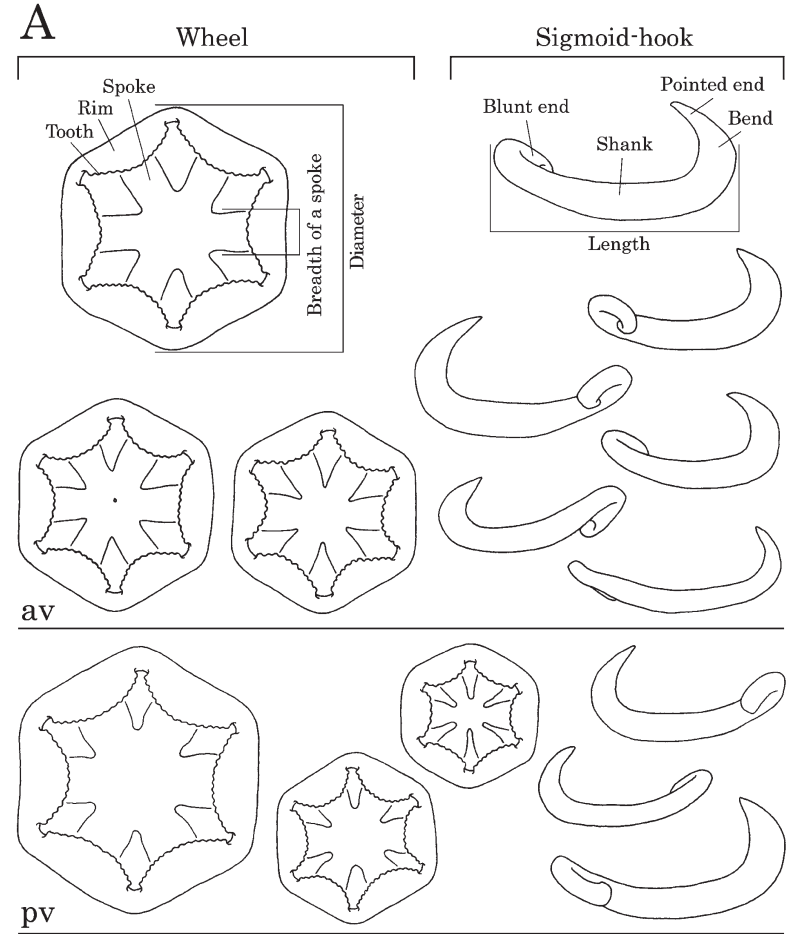

p
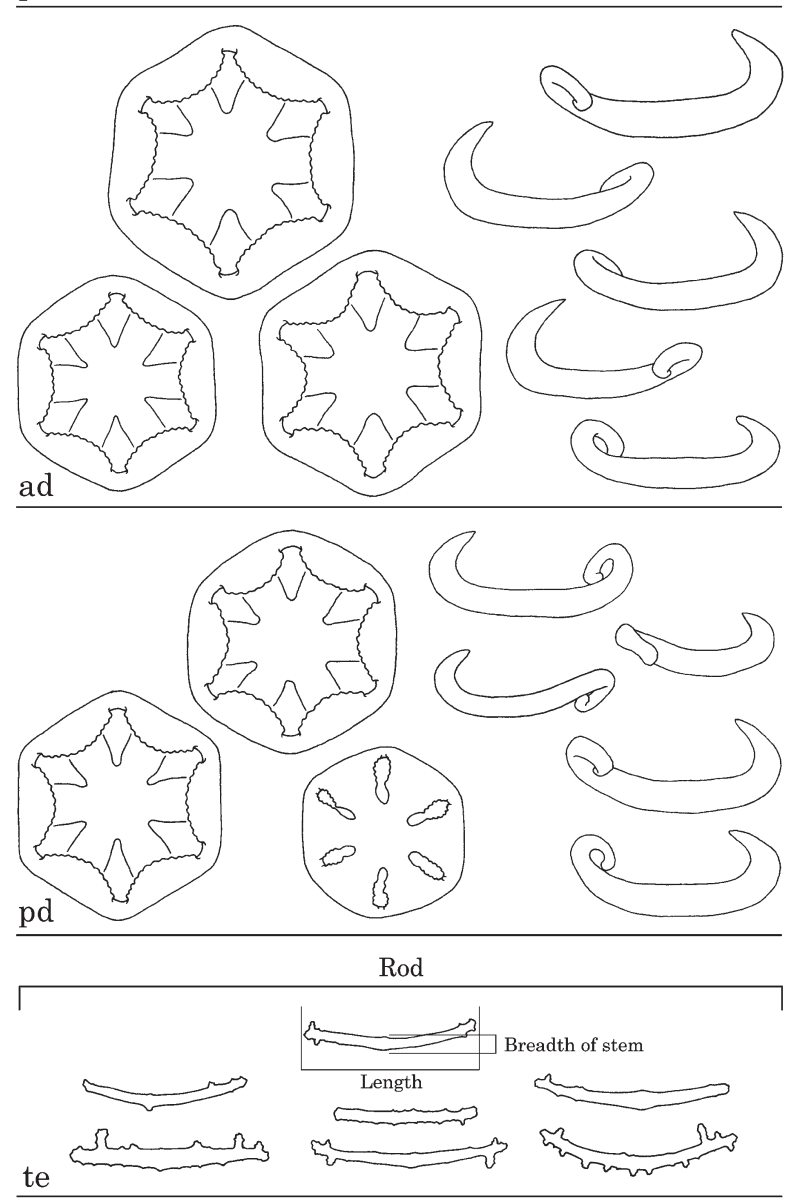
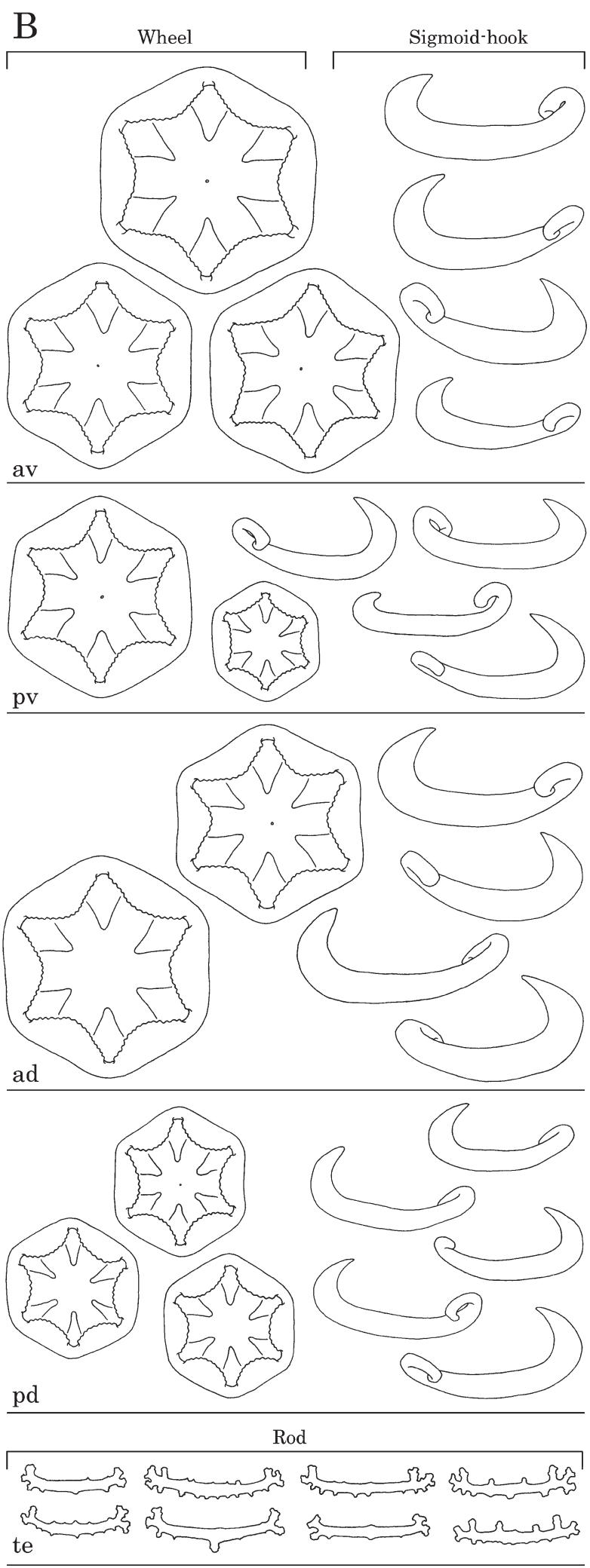

Fig. 8. Rowedota motoshimaensis sp. nov., ossicles from a tentacle and four parts of the body wall, and diagrams of their measurement axes, from WMNH-2015-INV-710 (paratype) (A); and WMNH-2015-INV-711 (paratype) (B). Abbreviations: ad, anterior dorsal; av, anterior ventral; pd, posterior dorsal; pv, posterior ventral; te, tentacle. 
wheel ossicles were observed, different from the present new species (Ohshima 1914). In T. misakiensis, wheel ossicles are confined to the three dorsal inter-radii (Ohshima 1914), which is different from the present new species. Although the descriptions of T. japonicus and T. roseus lacked detailed information, the following aspects were different from those of the present three new species. For T. japonicus, the colour in life "bloody red", and the tentacle digits numbering "14-16" (Marenzeller 1882); and for T. roseus, "colour in life pink", "tentacle with three pairs of digits", ossicles in tentacle "the same as in those of T. purpurea", and ciliated funnels in "mid-dorsal and left dorsal inter-radii" (Ohshima 1914).

The new Taeniogyrus species, T. mijim, has one pair of digits in each tentacle. Only two congeners have one pair of digits in each tentacle (or sometimes more): Taeniogyrus furcipraedita (Salvini-Plawen, 1972) (q.v.), and T. inexpectatus (Smirnov, 1989) (q.v.). Among these, T. inexpectatus from the Sea of Okhotsk was reported to have sometimes two or three pairs of digits on each tentacle, and the ossicles in the tentacles to have no spinous processes at all (Smirnov 1989). These features were not observed in T. mijim. The European species T. furcipraedita was reported to have extremely thin and weak spokes of the wheel ossicles, their breadth as measured from Salvini-Plawen's (1972) figure amounting to less than $10 \%$ of the diameter, and the tentacle ossicles had no spinous processes at all. These features were not observed in T. mijim.

Of the present two new species of Rowedota, R. chippiru has one pair of digits on each tentacle and thick-rod ossicles in the body wall. The only other species of Rowedota with one pair of digits on each tentacle is Rowedota vivipara (Cherbonnier, 1988), from which thick-rod ossicles were not reported (Cherbonnier 1988). Only one congeneric species, R. mira (Cherbonnier, 1988) has been reported to have thick-rod ossicles in the body wall, but it differs from $R$. chippiru in having 3-4 pairs of digits in each tentacle even in a very small specimen approximately $4 \mathrm{~mm}$ long (Cherbonnier 1988). The thick-rod ossicles in R. mira have previously been considered contamination (see O'Loughlin and VandenSpiegel 2010), but we confirmed their presence in $R$. chippiru, which implies that they may have been present naturally in R. mira as well. Most tentacles of Rowedota motoshimaensis had four digits, but this sometimes varied and two or three digits were also observed. We speculate that the tentacles with two or three digits were not yet fully grown. The number of tentacle digits in Rowedota may be highly variable even among specimens of the same species. Even the recent generic diagnosis (O'Loughlin and VandenSpiegel 2010) indicates that there may be 1-4 pairs of digits in the tentacles. Nevertheless, no species of Rowedota with just two pairs of digits as the maximum is known at present. Rowedota vivipara sometimes has three digits, but usually fewer and occasionally up to four digits. Its pattern of digit branching (Cherbonnier 1988) is apparently different from that of $R$. motoshimaensis: in $R$. vivipara with three digits, a central unpaired digit is flanked by a pair of digits.

In the present study, measurements of ossicles varied within a limited range. Within these ranges, however, the measurements of ossicle size from different body regions were sometimes significantly different among individuals, and ossicle size alone is not sufficient for a diagnosis. Reliable diagnoses must be based on both the range of sizes and the types of ossicles. In the wheel ossicles, at least the ranges of the diameter, number of teeth along the inner rim, and spoke breadth should be used for diagnosis. Future studies may show that additional detailed measurements (e.g., maximum and minimum breadth of rim, height and width of teeth, etc.) are also required.

Contrary to this, aside from a few species with distinctive sigmoid-hooks [e.g., Taeniogyrus yvonnae Moura et al., 2015 (q.v.)], the sigmoid-hooks of many chiridotid species are very similar. Their detailed shapes have not been thoroughly investigated, however. In the present study, aside from shank length, the shape of the sigmoid-hook in each species could not be quantified for possible use as a diagnostic feature because on slides they are not oriented all in the same plane. However, several features may distinguish the species, e.g., the width and angle of the bend and the breadth of the shank. A quantitative understanding of these features is a subject for future study.

\section{Acknowledgments}

We would like to thank Prof. Susumu Ohtsuka of the Takehara Marine Science Station of Hiroshima University for providing equipment for DNA analysis, and the entire staff of BIK and WMNH for invaluable assistance provided during this study. We also thank Dr P. Mark O'Loughlin and an anonymous reviewer for reviewing the manuscript; and Dr Keiichi Kakui and Dr Mark J. Grygier for careful editing. We are grateful to Mr Tohru Imaoka for his helpful advice. This work was partially supported by Research Institute of Marine Invertebrates (Tokyo) Grant 2015KO-1. Financial support for part of the microscopic observations was provided by Mr Shinichi Ikebe of the Supporters' Association of WMNH.

\section{References}

Altschul, S. F., Gish, W., Miller, W., Myers, E. W., and Lipman, D. J. 1990. Basic local alignment search tool. Journal of Molecular Biology 215: 403-410.

Altschul, S. F., Madden, T. L., Schäffer, A. A., Zhang, J., Zhang, Z., Miller, W., and Lipman, D. J. 1997. Gapped BLAST and PSI-BLAST: a new generation of protein database search programs. Nucleic Acids Research 25: 3389-3402.

Brandt, J. F. 1835. Prodromus descriptionis animalium ab H. Mertensio observatorum. Fascic. I. Polypos, Acalephas Discophoras et Siphonophoras, nec non Echinodermata continens. Recueil des Actes de la Séance Publique de l'Académie Impériale des Sciences de St. Pétersbourg 1834: 201-275.

Bucklin, A., Steinke, D., and Blanco-Bercial, L. 2011. DNA barcoding of marine Metazoa. Annual Review of Marine Science 3: 471-508.

Cherbonnier, G. 1988. Echinodermes: Holothurides. Faune de Madagascar 70: 1-292. 
Clark, H. L. 1921. The Echinodermata fauna of Torres Strait: its composition and its origin. Carnegie Institution of Washington Publication 214: 1-233.

Folmer, O., Black, M., Hoeh, W., Lutz, R., and Vrijenhoek, R. 1994. DNA primers for amplification of mitochondrial cytochrome $c$ oxidase subunit I from diverse metazoan invertebrates. Molecular Marine Biology and Biotechnology 3: 294-299.

Hebert, P. D. N., Cywinska, A., Ball, S. L., and deWaard, J. R. 2003. Biological identifications through DNA barcodes. Proceedings of the Royal Society London B 270: 313-321.

Heding, S. G. 1931. Über die Synaptiden des Zoologischen Museums zu Hamburg. Zoologische Jahrbücher, Abteilung Systematik 61: 637-696.

Imaoka, T. 1995. Holothuroidea. Pp. 553-572. In: Nishimura, S. (Ed.) Guide to Seashore Animals of Japan with Color Pictures and Keys. Vol. II. Hoikusha, Osaka. [In Japanese]

International Commission on Zoological Nomenclature 1999. International Code of Zoological Nomenclature, Fourth Edition. International Trust for Zoological Nomenclature, London, $306 \mathrm{pp}$.

Ludwig, H. 1898. Holoturien. Ergebnisse der Hamburger Magalhaensischen Sammelreise 1892-93 3: 1-98.

Marenzeller, E. 1882 [dated 1881]. Neue Holothurien von Japan and China. Verhandlungen der Zoologisch-Botanischen Gesellschaft in Wien 31: 121-140.

Moura, R. B., Campos, L., and Esteves, A. M. 2015. Hooked from the deep: a rare new species of Taeniogyrus (Holothuroidea, Chiridotidae) from the continental slope of Brazil, southwestern Atlantic. Zootaxa 3972: 535-548.

Ohshima, H. 1914. The Synaptidae of Japan. Annotationes Zoologicae Japonenses 8: 467-482.

Ohshima, H. 1915. Report on the holothurians collected by the United States Fisheries Steamer "Albatross" in the Northwestern Pacific during the summer of 1906 . Proceedings of the United States National Museum 48: 213-291.

Ohshima, H. 1919 [dated 1918]. [Holothuroidea in northwest Pacific. XX]. Dobutsugaku Zasshi 31: 139-149. [In Japanese]

O’Loughlin, P. M., Mackenze, M., VandenSpiegel, D., and Griffiths, H. 2015. New taeniogyrinid species of sea cucumber from the Weddell Sea (Echinodermata: Holothuroidea: Synaptida). Zootaxa 3995: 271-283.

O'Loughlin, P. M. and VandenSpiegel, D. 2007. New apodid species from southern Australia (Echinodermata: Holothuroidea: Apodida). Memoirs of Museum Victoria 64: 53-70.

O'Loughlin, P. M. and VandenSpiegel, D. 2010. A revision of Antarctic and Indo-Pacific sea cucumbers (Echinodermata: Holothuroidea: Apodida). Memoirs of Museum Victoria 67: 61-95.

Östergren, H. 1898. Das System der Synaptiden. Öfversigt af Kongliga Vetenskaps-Akademiens Förhandlingar 55: 111-120.

Östergren, H. 1905. Zwei Koreanische Holothurien. Archives de Zoologie Expérimentale et Générale, Series 4, Vol. III, Notes et Revue, $\mathrm{N}^{\circ}$ 8: 192-199.

Östergren, H. 1907. Zur Phylogenie und Systematik der Seewalzen. Pp. 191-215. In: Tullberg, T. (Ed.) Särtryck ur Zoologiska Studier Tillägnade. Almquist et Wiksell, Uppsala.

Parker, T. J. 1881. On a new Holothurian (Chirodota dunedinensis n. sp.). Transactions and Proceeding of the New Zealand Institute 13: 418.

Paulay, G. 2013. Taeniogyrus. World Register of Marine Species. Available at http://www.marinespecies.org/aphia.php?p=taxdetails\&id $=174000$ (9 September 2015).

Salvini-Plawen, L. V. 1972. Zur Taxonomie und Ökologie mediterraner Holothuroidea-Apoda. Helgoländer Wissenschaftliche Meeresuntersuchungen 23: 459-466.

Semper, C. 1867-1868. Holothurien. Reisen im Archipel der Philippinen, Teil 2, Wissenschaftliche Resultate. C. W. Kreidel, Wiesbaden, 288 pp.

Smirnov, A. V. 1989. A new species of holothurians Trochodota inexspectata (Synaptida, Chiridotidae) from the Simushir Island (Kuril Islands). Zoologicheskii Zhurnal 68: 156-160. [In Russian with English abstract]

Smirnov, A. V. 1998. On the classification of the apodid holothurians. Pp. 517-522. In: Mooi, R. and Telford, M. (Eds) Echinoderms: San Francisco. Balkema, Rotterdam.

Smirnov, A. V. 2012. System of the class Holothuroidea. Paleontological Journal 46: 793-832.

Solis-Marin, F. A., Komatsu, M., Soliman, T., Uchida, K., Shimotani, T., and Nozaki, M. 2014. Scoliorhapis danthus, a new species of sea cucumber (Apodida: Chiridotidae) from the Sea of Japan. Proceedings of the Biological Society of Washington 127: 323-327.

Utinomi, H. 1965. Holothuroidea. Pp. 82-99. In: Okada, Y., Uchida, S., and Uchida, T. (Eds) New Illustrated Encyclopedia of the Fauna of Japan Vol. III. Hokuryukan, Tokyo. [In Japanese] 